\title{
WHAT WAS ALL THE FUSS ABOUT? THE POPULAR-INTELLECTUAL POLEMIC
}

In the final years of the twentieth century, countless Chinese poets and critics partook in a protracted Polemic (论争) of Popular Writing (民间写作) and Intellectual Writing (知识分子写作) to which I have often referred in the preceding chapters. The Polemic made headlines in specialist and general media, and involved prominent players including Cheng Guangwei, Shen Haobo, Yu Jian, Yang Ke, Tang Xiaodu, Sun Wenbo, Wang Jiaxin, Han Dong, Xi Du, Xu Jiang, Yi Sha, He Xiaozhu, Chen Chao, Zhongdao and many others. All major protagonists were men. As noted more than once in this study, the male dominance of the avant-garde's metatextual arena is all the more remarkable in light of the significance of Women's Poetry as a textual category of widely acknowledged impact.

If we allow for some generalization, it would doubtless be possible to arrive at a textually argued contrast of so-called Intellectual and Popular poetry as written by the individuals associated with each side. The reader will recall that intellectual and popular form one of the dichotomies that constitute the overarching contrast of the Elevated and Earthly aesthetics within the avant-garde outlined in chapter One. However, literary texts per se played a negligible role in the Polemic. Instead, contributors put forward verse-external poetics more than anything else. What's more, for all their mutual hostility, Popular and Intellectual contributions to this particularly large and intense metatext exhibit some notable similarities. So, what was all the fuss about?

Section 1 of this chapter offers a critical inventory of over one hundred such contributions to outline what the issues were, that is: what people talked about. Section 2 considers geographical-cultural, institutional and biographical dividing lines and ties of allegiance (关系) between authors, and reflects yet again on the sociology of modern Chinese poethood, in order to identify what was at stake, that is: why people talked about what they talked about. The Appendix to this

(C) MAGHIEL VAN CREVEL, 2008 | DOI 10.1163/9789047442738_013

This is an open access chapter distributed under the terms of the Creative Commons AttributionNoncommercial 3.o Unported (CC-BY-NC 3.o) License. 
chapter contains a chronological bibliography of the Polemic, as a palpable record of its emergence and development and to facilitate future research. References to items \#1-120 are to the Appendix (in an in-text format to avoid drowning in bibliographical detail during the analysis); other literature, referred to in the footnotes, is found in the regular list of works cited for all chapters.

The Polemic was a defining, multi-faceted moment in discourse on the avant-garde. It was different from earlier tussles with the literary establishment as regards both the avant-garde's (self-)image and things like interpersonal relationships on the poetry scene, publication patterns and so on. There is an abundance of material and for developing a real sense of what it was all about, nothing less than immersion in the sources will do. To this end I will dwell on all key texts and make summary reference to many others. Hence, section 1 is long and dense, and some readers may wish to skip to section 2 (p441); but I have wanted to avoid jumping to conclusions on what was a rhetorically charged affair, and the material is well worth it. The analysis reaffirms a point that has come up several times in the preceding pages: on the contemporary Chinese poetry scene, images of poethood are of exceptional importance.

\section{What Were the Issues?}

The Polemic generated a plethora of publicly available material in multiple-author anthologies of poetry and criticism, scholarly publications, official and unofficial literary journals and regional dailies and weeklies. Research for this chapter doesn't extend to the Internet. Aside from the general disclaimer made in chapter One, this is because the explosive growth of Internet use on the poetry scene came after the Polemic "proper" had come to an end early in 2000.

\section{Cheng Guangwei's Appropriation of a Decade: "Chinese Poetry from the West"}

In February 1998 Beijing-based critic Cheng Guangwei published an anthology entitled A Portrait of Years Gone By: Literature of the Nineties, Poetry Volume (岁月的遗照: 九十年代文学书系, 诗歌卷, \#1). Literature of the Nineties (\#3) editor Hong Zicheng rightly calls attention to a change of mood in the 1990s as compared to the 1980s in a foreword (\#4) 
to the series, reaffirming that 1989 was a turning point between two distinct periods in contemporary poetry. Reflecting on the social status of (high) literature in the 1990s, which was much less self-evident than in the 1980s, Hong concludes on a note of cautious optimism, saying that in spite of poetry's low visibility some very good works have been written. Portrait also contains an introduction by volume editor Cheng Guangwei, entitled "Journey with Unknown Destination" (不知所终 的旅行, \#2). This essay had appeared by itself a few months earlier in Mountain Flower. Already at that time it must have raised some eyebrows, but it was as the introduction to the poetry volume in the Literature of the Nineties series that it sparked off the Polemic.

In "Journey," Cheng claims the concept of Poetry of the Nineties (九十年代诗歌) for a particular literary persuasion, which seemingly comes to monopolize what was in reality a decade of multifarious writing. ${ }^{1}$ Poetry of the Nineties then comes to denote the work of poets of Cheng's personal-professional preference, whom he frequently calls his "friends." Meanwhile, as his adversaries would be quick to point out, he ignores authors whose significance is beyond doubt, as evidenced by their publication record. Any anthology bears its maker's mark and subjectivity is the anthologizer's prerogative, and Cheng is by no means the only critic whose idea of "the Nineties" blurs the boundaries between aesthetics and calendar chronology, ${ }^{2}$ but the introduction to Portrait and its selection of poems are blatantly partial. This is borne out by an appendix listing Cheng's recommendations in poetry and criticism on the book's final page. All things considered, it is hardly surprising that the anthology gave rise to heated debate.

For his vision of Poetry of the Nineties, Cheng takes his cue from the work of Wang Jiaxin. This passage (p2) ${ }^{3}$ is reprinted on the book's back cover:

\footnotetext{
${ }^{1}$ As noted in chapter One, my use of the Eighties and the Nineties is with reference to a sea change in the intellectual-cultural realm at large, as distinct from the 1980s and the 1990s as neutral indications of calendar time. This distinction is acutely relevant to the present chapter.

${ }^{2}$ Cf Luo Zhenya 2005: 172-188 and Wei 2006.

${ }^{3}$ Page numbers are those of first publications. Cheng Guangwei's "Journey" is one of three exceptions $(\# 2,63,86)$. Reference is made to the article in its capacity as the introduction to Portrait, because it is as such that it triggered the Polemic.
} 
I was shocked by the feeling of grief in [Wang's] poems, and I felt that it was not just him, but that all this encompassed shocking changes deep inside the souls of our entire generation. I had a premonition that the Eighties were over. Or, perhaps, that what used to be knowledge / intellect, truth, experience, no longer constituted "models" to regulate, to guide, to control what poets write, and at the very least these things no longer provided any norms for writing.

My rendition of 知识 'knowledge' as knowledge / intellect is motivated by its various uses by various parties in the debate, and by its connection with the Chinese 知识分子 'intellectual.'

According to Cheng Guangwei, knowledge / intellect is a good thing, even if it found itself floundering throughout the 1990s. As noted in chapter Five, following the 1987 edition of the Poetry Monthly Youth Poetry Conference at Shanhaiguan, several up-and-coming poets had advocated an "intellectual spirit" for poetry and arranged for their ideas to materialize in the unofficial journal Tendency the following year. With reference to this self-assigned label, Cheng Guangwei calls his favorite poets Intellectuals. Judging from the space he devotes to them in his introduction to Portrait, in addition to Tendency founders Chen Dongdong, Xi Chuan and Ouyang Jianghe-from the mid-1980s, Ouyang had played a particularly prominent part in the theorization of "serious" or "intellectual" poetry" - they include Wang Jiaxin, Zhang Shuguang, Xiao Kaiyu, Sun Wenbo, Bai Hua, Zhai Yongming and Zang Di. Cheng holds that (p17)

Nineties writing requires the writer first of all to be an intellectual with independent views and taking an independent position, and only then to be a poet.

Die-hard supporters of Maoist literary policy aside, it would be difficult to find anyone in post-Cultural-Revolution China who disagrees with the need for the writer to hold independent views and take an independent position, but the primacy of intellect over poethood is of course open to debate.

In principle, many voices on the poetry scene might have concurred with Cheng's moralizing (p15-16):

I respect the efforts of those few poets of the Eighties who were serious about their writing . . What we call poetry of the Nineties . . . is

\footnotetext{
4 Day 2005a: ch 8.
} 
an extremely strict artistic standard, it is a moral issue in the writing of poetry.

The problem was that Cheng appropriated the full breadth of a decade for only one of many poetic practices that co-existed at the time.

One thing that angered many was Cheng's negotiation of an issue which has remained controversial ever since Huang Zunxian's experiments with the vernacular in the final years of the nineteenth century, namely Chinese poetry's relationship with foreign and especially "Western" literature. First, Cheng lists numerous foreign influences, but without textual evidence, so that this amounts to little more than name-dropping. When discussing Zhang Shuguang, whose poem «Ulysses» (尤利西斯, 1992) is included, Cheng mentions Yeats, Rilke, Miłosz, Lowell and Pound; for Wang Jiaxin, whose «Pasternak» and «Kafka» (卡夫卡, 1992) are included, Yeats, Miłosz, Pasternak and Brodsky; for Zhai Yongming, Sylvia Plath; for Xi Chuan, whose «Rereading Borges' Poetry» (重读博尔赫斯诗歌, 1997) is included, Borges, Neruda and Pound; for Chen Dongdong, Apollinaire and Breton; and for Xiao Kaiyu, "certain American poets" and Pound. The echo Cheng hears of Chinese traditions moves him to no more than one mention of Republican-era poets Li Jinfa and Dai Wangshu in connection with Chen Dongdong, and one of Tang and Song dynasty poets Li Shangyin, Wen Tingyun and Li Yu in connection with authors of lesser prominence in his anthology.

A second bone of contention was Cheng's depiction of Chinese poetry's relationship with its Western precursors and examples. This is the operative passage (p18):

There is a notion that traditional Chinese poetry never offered modern poetry a suitable aesthetic space, and that therefore one can say that modern Chinese poetry has grown and developed in another aesthetic space, that is: within the Western poetic tradition. Such a notion presents us with the hypothesis that people could only discuss Poetry of the Nineties within the boundaries of Western taste. I do not doubt that our poets have wanted to dedicate themselves to modern Chinese poetry with all the sincerity and responsibility contained in the greatness of their character; but I do doubt whether the ordeal of their dilemma has contributed to the rational development of our modern poetry. On the one hand we look to Pound, Eliot, Auden, Yeats, Miłosz, Mandelstam, not to mention the biases and ever-changing tastes of foreign sinologists, and we attempt to establish what is in fact the fiction of a "tradition" of modern poetry in Chinese; on the other, in our heart of hearts, in the insight 
into Han culture and language that is carved into our bones, we lack any and all confidence regarding this "tradition," which is built on sand. We are sufficiently vigilant vis-à-vis the "international poetry stage" but at the same time yearn for recognition on that very stage, to use this as a standard for greatness in poets. On the one hand we want to be Don Quixote charging enemy lines; on the other, even if we have taken a hundred steps forward, we are still but an irresolute, hesitant Hamlet. Our education and our nature preclude all this being more than fruitless exercises in the realm of art.

Tellingly, Cheng concludes this passage by references to Don Quixote and Hamlet, and not, say, Sun Wukong and Ah Q. In 2001 his views on the matter were brief and simple: modern Chinese poetry comes from the West. ${ }^{5}$

Third, Portrait takes its title from an eponymous poem (1993) by Zhang Shuguang, which opens the anthology (p1-2):

"A Portrait of Years Gone By"

Over and over again I see you, friends from childhood days still lively, cheerful, with your jokes that border on the vulgarit seems the years have failed to play their tricks on you or you've somewhere found a prescription for staying young and the trees, the sky behind you still retain their original shape, not a hint of change, as if bravely withstanding time and all that time brings. Oh young knights, we once saw days of glory, drank and womanized or stayed up all night to talk about a poem or a novel. We played Hamlet, now imagine crossing the waste land, looking for the long-lost holy grail near the campus flower beds at dusk, chasing Eliot's lonely silhouette. At the time I didn't like Yeats, didn't understand Lowell or Ashbery and of course didn't know you, merely saw you every day hurrying along that little road to the church or the canteen, your expression grave or melancholy. I went mad for the illusion of an image, called out for spring only to be cast deeper into valley snow until my soul was exhausted. Of the squirrels back then some are now dead some toothless left with no more than the occasional angry cry to prove that they're here and we've made peace with our fathers, or become fathers or fallen into even deeper traps in life. And do they really exist those beautiful hours that we yearn for, gone forever? Or

\footnotetext{
${ }^{5}$ Personal communication, July 2001.
} 
are they but dreams, or ideas we entertain within our pain?

Perhaps we're only witnesses to time, just like these old photographs

yellowed, cracked, but holding events, people

once called history, yet never real-

The poem's second half is stronger than its first. What concerns us here is these lines:

to talk about a poem or a novel. We played Hamlet, now imagine crossing the [W] aste [L] and, looking for the long-lost holy grail near the campus flower beds at dusk, chasing Eliot's lonely silhouette. At the time I didn't like Yeats, didn't understand Lowell or Ashbery

There is no reason why a Chinese poet shouldn't refer to Western traditions. Also, the text holds not a single clue regarding the cultural identity of the speaker, unless we want to take the fact that it is written in Chinese as such. Should we perhaps envisage the speaker as a Westerner, precisely because he speaks of Hamlet and the rest? The casual transition from public, historical, literary Westerners to an anonymous, personal presence (you) in his life doesn't make this a likely reading. Be that as it may, without condoning cultural nationalism and protectionism, it is understandable that the combination of the anthology's subtitle, Cheng Guangwei's introduction and his naming of the book after Zhang's poem rubbed many readers the wrong way.

\section{Shen Haobo's Angry Response: "The Occupation of the Poetry Scene"}

An elaborate rejoinder to Cheng Guangwei's anthology and its introduction would appear early in 1999, in what may well be called a counter-anthology edited by Yang Ke, with a counter-essay by Yu Jian. But let's first take a look at an earlier contribution by Shen Haobo, who would soon take the lead in the Lower Body movement. In October 1998 Shen - then calling himself Choushui-had published “Who's Fooling “the Nineties” (谁在拿 “九十年代” 开涮, \#8) in the May Fourth Literary Fournal (五四文学报) at Beijing Normal University, where he was a student at the time. It was first reprinted in Oriental Culture Weekly (东方文化周刊), and then, in January 1999, in the widely read Friends in Letters (文友). The article, sometimes more like an open letter to Cheng Guangwei, starts off in bold, vituperative terms (p20): 
... I mostly want to talk about these people: Cheng Guangwei, so-called "famous" poetry critic, whom I have always disliked; Hong Zicheng, professor at Peking University, whom I once respected but whose behavior I now find most dubious; Ouyang Jianghe, high school graduate bragging all day long about being an "intellectual"; Wang Jiaxin, forever jabbering foreign names like "Pasternak" and "Brodsky," words like "exile" and "grief"; Sun Wenbo, who has written a hundred bad poems, all with the same face, but is still trying hard to establish himself in Poetry of the Nineties; Chen Dongdong, whose pages are strewn with exquisite expressions but who can't string together a single good poem; Xiao Kaiyu, who is in no way worth mentioning but now affects sudden fame; and those lower down, like Zhang Shuguang, Zang Di and Xi Du and their ilk.

Shen Haobo is a skilled polemicist. That is, for all the ostentatious subjectivity of his allegations, they are put forward with enough panache to leave a lasting impression. He sounds both threatening - toward the end of the article, when he addresses Cheng Guangwei directly - and sardonically funny, as in this attack on Wang Jiaxin (p21):

. . Granted, Wang Jiaxin's «Pasternak» is a good piece of work, but that's all. In most of his poems, the best lines are always those in quotation marks (and what he quotes is other people's poetry!). He is always in London or in Russia, always pouring out his Brodsky, his Pasternak, his Kafka - he simply doesn't grow on Chinese soil! All day long, over and over again, he says "exile" "exile" "exile," but the problem is: who is it has exiled you, Wang Jiaxin? You're not Bei Dao, you're not Duoduo, you're not Brodsky, and you will always be that overcautious Wang Jiaxin, imitating the Russians with that big scarf'round your neck, Wang Jiaxin!

Shen feels that Cheng Guangwei and poets, critics and editors of similar inclination have "occupied" important channels for publication in the 1990s and intentionally "suppressed" worthy poets such as Yu Jian, Yi Sha, A Jian, Mo Fei, Hou Ma, Xu Jiang, Han Dong and Wang Xiaoni. His words contain some of the charges against the Intellectuals that were to recur throughout the Polemic: Westernization and the lack of an indigenous spirit, affected, mystifying diction, and manipulation of opportunities for publication and public relations of the poetry scene. 


\section{Yu Fian's Two Camps in Poetry: "The Light of the Chinese Language"}

Early in 1999 Guangzhou-based poet and editor Yang Ke put out the 1998 Yearbook of China's New Poetry (1998 中国新诗年鉴, \#12). For its coverage of one year, the 1998 Tearbook is an ambitious project. In fact, its selection of poetry by close to a hundred authors and of essays by a dozen critics includes entries from earlier years. Yang Ke's anthology was followed in April by another yearbook, edited by Beijing-based critic and editor Tang Xiaodu, entitled 1998 Yearbook of Modern Han Poetry (1998 年现代汉诗年鉴, \#17). Tang's book, with a broad vision but more meticulously organized than Yang's, contains works by well over a hundred poets and three appendices of specially recommended poems, criticism and events in poetry in 1998; as we have seen in earlier chapters, the Han in Modern Han Poetry denotes the Chinese language rather than ethnicity. Tang's choice of material for the appendices would likely have reaffirmed the discontent Shen Haobo felt at what Shen perceived as the occupation of the poetry scene by certain poets and critics.

The successive appearance of Yang's and Tang's yearbooks in Guangzhou and Beijing, the composition of their editorial committees and Yang's postscript (\#13) all point toward what would soon be one of the central issues in the Polemic: a dichotomy of North and South, and of Beijing and the provinces. Yang Ke's is arguably a counteranthology to Cheng Guangwei's A Portrait of Years Gone By, and it is spearheaded by a counter-essay by Kunming poet Yu Jian. Yu's essay, entitled "The Light of Poetry, Cutting through the Chinese Language" (\#14), amounts to a declaration of war.

"The Light" was written in the fall of 1998. A year earlier, when Cheng's Portrait had just come out, important elements in "The Light" had been foreshadowed in Yu's "The Hard and the Soft of the Tongue of Poetry: On Two Different Directions in the Language of Contemporary Poetry" (\#5), published in Poetry Exploration; we encountered both essays in chapter Eleven. "The Hard and the Soft" is less truculent than "The Light," presumably because it went to press before Cheng Guangwei's book claimed the 1990s for the poetics of Cheng's preference.

In "The Hard and the Soft," Yu Jian examines the development of contemporary poetry through a contrastive comparison of the Standard Language and regional languages. In Yu's words, there is 
a connection of the Standard Language, Maoist discourse, central state-sanctioned ideological and literary orthodoxy, official realities of propaganda and the public sphere, utopianism, abstraction, metaphysical spirituality, formal diction, foreign-influenced literary elitism, Intellectual Writing and so on - what he calls a hard (硬) type of language - with works by orthodox Political Lyricists He Jingzhi and Guo Xiaochuan, Obscure and Post-Obscure poets such as Bei Dao, Yang Lian, Wang Jiaxin, Haizi, Ouyang Jianghe and Xi Chuan, and poet of the masses (大众) Wang Guozhen. The obvious implication is the relegation of Bei Dao, Yang, Wang, Haizi, Ouyang and Xi Chuan to an orthodox and artistically hackneyed position, in spite of their generally perceived avant-garde status. Yu Jian writes that, on the other hand, regional languages, life in the (Southern) provinces, marginality, unofficial realities, relaxation, humor, playfulness, intimacy, concreteness, physicality, indigenous culture, colloquial diction, Popular Writing and so on - in what he calls a soft (软) kind of language - are found in works by Third Generation authors such as Han Dong, Yu himself, Lü De’an, Zhai Yongming, Yang Ke, Zhu Wen, Lu Yimin and Yang Li. In itself Yu Jian's attention to differences between the Standard Language and regional languages is entirely justified, but the leaps and bounds that lead to his literary genealogy remain unsubstantiated.

Still, "The Hard and the Soft" is a paragon of reason and clarity when compared to "The Light" and to several of Yu's later contributions. Yu Jian offers original ideas but his style is often gratuitous, chaotic and aggressive. Like Shen Haobo, he achieves considerable effect because he excels at invective, has an unfailing instinct for what is hip in artsy and "ordinary" circles, and can be very funny. "The Light" suffers from a questionable internal logic, but it contains most of the core elements of the Popular-Intellectual Polemic.

Before we proceed to review these, another translatory note is in order, on 民间 'popular,' 'folk,' 'of the people,' 'among the people,' 'people-to-people,' 'non-governmental,' rendered as Popular throughout this study. This rendition has an unfortunate overlap with popular as in 通俗读物 'popular reading matter' in the sense of pulp fiction. On the other hand, rendering 民间 as of the people would lead to unwarranted association with 人民 'the people,' a key term in PRC political discourse, in phrases like 人民共和国 'the People's Republic' and 人 民群众 'the masses of the people.' People-to-people or non-governmental only cover a small part of the connotations of 民间 in the Polemic. 
Furthermore, as we shall see, Yu Jian and others use 民间 in two different ways, which further complicates its translation. Hence, Popular remains the preferred option after all, with upper-case $\mathrm{P}$ - and uppercase I in Intellectual - flagging usage that is specifically linked to the Polemic. The possibility of throwing up our hands at an instance of untranslatability and simply transcribing it as minjian is denied us, because the word's usage in the Polemic is equally problematic in the original. ${ }^{6}$

But let's return to the scathing criticism of Cheng Guangwei's scheme of things put forward by Yu Jian in "The Light." Yu expands the scope of the conflict to that of total warfare between two camps in poetry, one of Intellectual Writing and one of Popular Writing. Notwithstanding his 1993 statement that an intellectual standpoint was a minimal condition for mature poethood, ${ }^{7} \mathrm{Yu}$ presents himself as a champion of the Popular. His argument hinges on a rhetorically clever usage of Popular that invests it with two profoundly different implied meanings, one institutional and the other aesthetic, along the lines of a similar ambiguity in the term unofficial, discussed in chapter One. In Yu's essay, Popular sometimes takes on the institutional meaning 'published outside state control,' as a proud epithet of groundbreaking journals such as Today, Them and $\mathcal{N}_{\text {ot-Not. }}$. At other times he uses Popular in an aesthetic sense, so that the question What is Popular poetry? is implicitly rephrased as What is good poetry? or What is poetry that matters? He contends that good poetry is inherently opposed to knowledge / intellect, and describes Popular poetry as a reflection of the experience of everyday life, craftsmanship like that of a carpenter, the movement of language which cuts through forgetting and returns to the home of being, the light emitted by wisdom and the soul, and so on. Other, equally vague and high-blown definitions abound. The most interesting among them spring from Yu Jian's concern with language itself rather than things like truth and beauty.

Yu's impassioned advocacy of Popular Writing in both the institutional and the aesthetic sense implies the identification of Intellectual Writing with state-sanctioned orthodoxy on both counts. If Intellectual Writing is presented as alien to Popular Writing in the aesthetic sense, the non-specialist reader may well assume that institutionally, it had

\footnotetext{
${ }^{6}$ Cf Wang Guangdong 2002.

Yu Jian \& Zhu 1993, published as 1994: Question 5.
} 
no part in the avant-garde's history either, which would retroactively make its authors disappear from the unofficial journals that have been instrumental in this history. As the avant-garde was originally defined in opposition to orthodoxy and has effectively outshone it since the mid-1980s, hostile identification with orthodoxy is a damaging imputation for any avant-garde author.

$\mathrm{Yu}$ Jian characterizes Intellectual Writing as elitist, artificial, alienated and fake, and Popular Writing as sensitive, honest, accessible and authentic, and belonging to ordinary people. In line with his ideas on the hard and the soft, Intellectual Writing is located in the North, more specifically in Beijing and the Standard Language, as the center of orthodox, political ideology; and Popular Writing is located in the provinces, more specifically the South and its regional languages, as the heartland of Chinese culture. The opposition of North and South extends into one of foreign and Chinese. Yu ties Intellectual Writing to foreign-colonial traditions and what he calls the slavish Europeanization of a Chinese language that draws on Western-language resources (西方语言资源). Exile poetry doesn't count as Chinese. Popular Writing, in its turn, taps into the Chinese experience and into pride taken in indigenous traditions, such as the classical poetry of the Tang and Song dynasties. He concludes with a remark on the possibility that some languages are better suited to certain tasks than others (p16):

For poets of the Chinese language, English is a language for the web, a Standard Language for the cloned world that leads the way in our time's economic activities. But for poetry the world needs Chinese to take the lead. The historical consciousness of the Chinese language and its natural poetic qualities make it a poetic language par excellence that can effectively maintain human memories of the earth and the connection of humankind's spirit with the old world. I am of the opinion that in the final two decades of this century, the world's most outstanding poets have dwelled in the Chinese language. But on this point we remain silent, we keep it a secret and don't spread the word.

As noted in chapter Eleven, the assumption appears to be that foreigners don't read Chinese, and one wonders why those parts of the world that lie outside China should be kept in the dark if the world's best poets are really writing in Chinese. These things sit uneasily with the importance $\mathrm{Yu}$ Jian ascribes to the Chinese language for the wellbeing of humankind. Then there is the sad lot of languages which are neither English nor Chinese, disabling them for leadership in matters 
economic and poetic alike: say, Swahili, Finnish, Turkish, Portuguese, Hindi, Russian, Arabic....

The above passage is typical of Yu Jian's disregard for argumentative logic or nuance. Sometimes this rhetorical havoc appears to be intentional, as in the distortion of Cheng Guangwei's opinions. The struck-out words are those that Yu Jian leaves out when he quotes Cheng (p8):

Nineties writing requires the writer first of all to be an intellectual with independent views and taking an independent position, and only then to be a poet.

"The Light" and Yu Jian's other essays are cluttered with untenable claims: historical events such as the founding of the People's Republic and June Fourth are irrelevant to the development of literature, poetry was part of the everyday experience of ordinary people in the Tang and Song dynasties, something similar is currently true for Popular poetry by $\mathrm{Yu}$ and others, and so on. A conspicuous feature of his contributions and of the Polemic at large, mostly in the Popular camp, is the echo of Maoist literary discourse, or perhaps we should say its resuscitation in a vastly changed context. This is manifest in the negative stereotyping of Intellectual status, and in the overall tendency toward moralizing, righteous verbal assault in a manner that recalls the preaching of political ideology. It is disconcerting if we bear in mind some of the less pleasant experiences forced on intellectuals in the Maoist years, and the avant-garde's tense relationship to a cultural orthodoxy that theoretically still adheres to Maoist literary ideas. Yu Jian displays a curious anti-intellectualism in passages like the following (p8):

The inherent deficiency of [contemporary] criticism has led it to rely solely on the "Intellectuals" for its theoretical resources, in the end losing the independent standpoint of criticism and degenerating to a level not much different from that of poetry authorities such as those rigid, "bookish" poetry professors in universities, poetry critics, Chinese Departments and anthologies.

Yu's anti-intellectualism combines Maoist overtones with an opposition of the creative and the critical in literature. Notably, this opposition springs from a modern, romantic vision of the artist that is incompatible with Maoist theory. In addition, whenever it supports their argument, $\mathrm{Yu}$ and his comrades-in-arms use Intellectual to mean 
'having completed a certain level of formal, higher education.' This is awkward because many in the Popular camp hold degrees from universities of repute. Yu Jian and Shen Haobo are graduates of Yunnan University and $\mathrm{BNU}$ respectively, and $\mathrm{BNU}$ is also alma mater to $\mathrm{Xu}$ Jiang and Yi Sha, whom we will encounter below. Xie Youshun and Han Dong, another two Popular polemicists of note, are graduates of Fujian Normal University and Shandong University.

We have noted the Popular emphasis on the value of indigenous culture and its rejection of Westernization. Of course, especially in modern times, there is no such thing as a purely Western or a purely Chinese culture. Incidentally, the reader will recall that $\mathrm{Yu}$ Jian has identified Walt Whitman's and other foreign poetry as having had a tremendous impact on him in his years as a budding poet, also mentioning Pushkin, Lermontov, Shelley, Byron and Tagore as examples of the Western literature he read during the Cultural Revolution, usually in a deserted library in Kunming. Yu's extensive if eclectic acquaintance with foreign literature in translation doubtless continued afterward, as it did for most Chinese authors who rose to prominence in the 1980s and 1990s. ${ }^{8}$ While it may be an exaggeration to charge the Popular cause itself with nationalism in any serious sense, as Wang Jiaxin (\#23) has done, authors such as Sun Wenbo (\#81) and Geng Zhanchun (\#6) have a point when they observe that Popular ideas ride the tide of reemergent nationalism in China at large. These are the closing sentences of "The Light" (p17):

Poetry in Chinese of the last twenty years goes to show that my dreamof rebuilding a dignity that the Chinese language had nearly lost since [the Opium Wars], of letting modern Chinese obtain anew the glory that the Chinese language once had, in the poetry of the Tang and Song dynasties - that my dream is not at all a dream, but a magnificent road to travel.

\section{Xu fiang's Vitriolic Clowning: "Ordinary People's Right to Poetry"}

Poet Xu Jiang shares Yu Jian's nostalgia for the glory of classical Chinese language and poetry. In his "One Man's Polemic" (一个人的论 争, \#71), Xu writes (p97):

\footnotetext{
${ }^{8}$ Yu Jian \& De Meyer 1995: 28.
} 
As a poet of the Chinese language, my sorrow lies in not having been born in the days of [Tang and Song dynasty poets] Li Bai and Su Shi.

Like Yu Jian, too, $\mathrm{Xu}$ is ready to do battle on behalf of his ideals:

I have a responsibility to protect the soberness, cleanliness and fairness of the Chinese poetry scene, and I cannot let a small handful of pedantic literati slackly gain undeserved reputations, while destroying literature and the Chinese language.

The phrase a small handful of pedantic literati takes us straight back to the spring of 1942 in the Communist base areas, when Maoist literary policy was taking shape, and the same is true for Xu Jiang's fondness for calling the Intellectuals comprador-poets (买办诗人). The echoes of orthodoxy also run through Xu's “Ordinary People's Right to Poetry" (俗人的诗歌权利, \#25) and through his most substantial and acrimonious contribution to the Polemic, “The Noxious Poetry Scene” (乌烟 瘴气诗坛子, \#16). This long article appeared in the March 1999 issue of Friends in Letters. Having earlier published Shen Haobo's "Who's Fooling "the Nineties," this monthly magazine would continue to support the Popular side. In "The Noxious Poetry Scene," conjuring up the image of a miasma rising from the swamps of literature, $\mathrm{Xu}$ levels wide-ranging accusations at the Intellectual camp and blames Cheng Guangwei for leaving the reader with this impression (p6):

All Chinese poets of the Nineties are a bunch of sickly aphasia patients, not one of them can speak in plain words! . . If it weren't for the fact that I write poetry myself, even I would almost believe what he has to tell us: poets aren't normal people!

The article is divided into three parts, with subheadings "Those Anthologies," "Those Poetry Awards" and "Those Poets." The first contains yet more devastating criticism of Cheng's anthology. The second is about the corruption $\mathrm{Xu}$ Jiang perceives behind poetry awards conferred in the name of Liu Li'an, also known as Anne Kao, patroness of the avant-garde at the time and perceived by some to be partial to the Intellectuals. The third is a remarkable call to poets to behave themselves (p7):

[The poets] are lacking in discipline-long-haired or with shaved heads, living vagrant lives, giving speeches, reciting poetry, cadging meals, talking all sorts of strange prattle, presumptuous and full of themselves. 
Xu's rhetorical talent is on display when he sums up the relationship between these undisciplined poets and other, presumably "normal" people. In a nutshell: in the 1970s people were afraid of poets, in the 1980 s they were curious about them and in the 1990s they were annoyed by them. That Xu Jiang subsumes murder under annoying behavior is persuasive enough, in an oblique reference to $\mathrm{Gu}$ Cheng's killing of Xie Ye before taking his own life. That suicide should also count as annoying, rather than give cause for concern, is less selfevident. Judging by Xu's other publications, out of several suicides in avant-garde poetry since the late 1980s we should probably be thinking of Haizi here. Members of the Popular camp recognized Haizi's talent, but they still associated his life and work with the self-aggrandizement and the estrangement from everyday Chinese life for which they took the Intellectuals to task. Finally, Xu Jiang chides Poetry Monthly's editors for including their own names in a list of influential authors, as an illustration of Chinese poets' flagrant indulgence in self-promotion. Then he promptly names one of his own collections, this one in joint authorship with Hou Ma, among the ten best books of poetry of the past twenty years.

$\mathrm{Xu}$ Jiang's contributions to the Polemic are notable not so much for their substance as for their linguistic register. His choice of words and his overall tone of voice are rude and clownish at the same time. "Playing Chinese Poetry" (玩弄中国诗歌, \#11), preceding “The Noxious Poetry Scene" by a month and containing sideways allusions to the early stages of the Polemic, is a case in point. Here, $\mathrm{Xu}$ describes contemporary poetry as a sport, laying out the rules and various types of players to comical effect. The rude and the clownish merge when he admonishes aspiring critics to (p21)

put forward incessant, long articles on the work of women poets that nobody has ever heard of.

The 1999 issue of Poetry Reference includes Xu Jiang's "This Is My Standpoint" (这就是我的立场, \#72). This article makes clear how far $\mathrm{Xu}$ is willing to go in his diatribes against the Intellectuals. He accuses Wang Jiaxin of plagiarizing Pasternak, and lambastes him for (p87)

his sudden realization that for exile poetry, you don't need to go abroad.

$\mathrm{Xu}$ Jiang obviously feels no need to reflect upon niceties such as the scope of the notion of exile literature beyond its most "common- 
sensical" interpretation. The poet's whereabouts aside, Xu also has clear ideas about the preferred geographical location of their subject matter, reproaching Wang for writing about Auschwitz rather than the Nanjing massacre or the Cultural Revolution.

As we have seen in chapter Nine, on the "rivers and lakes" of the poetry scene Xu Jiang is a close companion of Xi'an-based poet Yi Sha, who has generated more controversy than anyone else since his famed collection Starve the Poets, and whose contributions to the Polemic we will address below. ${ }^{9}$ Yi Sha's and Xu Jiang's willful notoriety for abusing fellow literati and artists is captured in a March 2000 interview with Shen Haobo, using the name Shen Lang, with the tonguein-cheek title "Carry Abuse Through to the End" (将骂人进行到底, \#91). This headline is a typical parody of orthodox political jargon. It makes Yi's, Xu's, Shen's and others' penchant for seriously using such language elsewhere all the more remarkable.

\section{Xie Youshun's Cheerless Aggression: "The True Face of Poetry"}

Nevertheless, while Xu Jiang's and Yi Sha's diction is regularly reminiscent of orthodox discourse, it is also interspersed with other types of language: humorous, populist, vulgar and so on, and it leaves plenty of room for creative originality. This doesn't hold for the critic Xie Youshun. Xie specializes in fiction, but contributed several articles to the Polemic. "What Does Poetry Relate to?" (诗歌与什么相关, \#15), published in the March 1999 issue of Poetry Exploration, boils down to the assertion that poetry should be about "real life." Xie proceeds from a narrow-minded biographism, and his view of literature is almost anticreative when he presupposes a simple, one-on-one relationship between reality and art. His style, a prime example of the aforesaid echo of Maoist literary discourse, is cheerless and aggressive throughout.

One piece that elicited a fiery response from Intellectual quarters is Xie's "The Inner True Face of Poetry" (内在的诗歌真相, \#20), a rave review of Yang Ke's 1998 Yearbook carried by Southern Weekend (南方周末). Xie wonders if writing poetry is not a comical thing to do in an age of materialism, and observes that jokes about poets abound among ordinary people. He finds this especially lamentable in light of the proud poetic traditions of the Tang and Song dynasties. According

\footnotetext{
${ }^{9}$ Yi 1994.
} 
to Xie, the public has forsaken poetry because a number of poets have turned it into knowledge / intellect and abstruse learning. He advertises Yang Ke's yearbook as an attempt to countervail this trend. Following $\mathrm{Yu}$ Jian, as he does in most of his contributions to the Polemic, he sees two prominent types of poetry. Popular Writing is represented by poets such as Yu Jian, Han Dong and Lü De'an, and expresses the realities of current Chinese life. Intellectual Writing is represented by poets such as Xi Chuan, Wang Jiaxin and Ouyang Jianghe, who have an ardent desire to "connect" with the West - one recalls Yu Jian's displeasure at this phenomenon. Again, like Yu Jian before him, Xie misquotes Cheng Guangwei's vision of the poet as an Intellectual. Xie fails, however, to name the author of the mutilated statement, and instead ascribes it to Xi Chuan, Wang and Ouyang, thus saddling them with Cheng's sins. He adds that if poetry is to regain vitality it must be freed from the hegemony of Intellectual discourse. Xie is one of several voices in the Polemic that blend poststructuralist terminology with incrowd allusions to texts, people and events on the local poetry scene that only the initiated reader will pick up. Another feature he shares with contributors from both camps is that his article ends with a thunderous finale. The closing words of "The True Inner Face" have a nationalist ring to them:

Does poetry protect a self-respecting life or does it protect knowledge / intellect and technique? Is the goal of poetry in the Chinese language to regain the dignity of the Chinese language or is its goal to connect with the West? I believe that in their heart of hearts every sensitive person will swiftly make their choice.

Xie Youshun disapproves of undue reliance on the West, visible in things like the density of foreign names in Zhang Shuguang's poetry: not only in Cheng Guangwei's anthology, but also in journal publications, as Xie notes in his "Poetry Is Hurting" (诗歌在疼痛, \#68), in the October 1999 issue of Grand Master (p72):

[The Intellectuals] cannot hear the voice of Popular poetry, not because it isn't there but because they haven't drawn back their ears from the bodies of the Western masters.

Xie's plea for indigenous dignity is at odds with his own habitual citation of Western authors and critics rather than Chinese. In the limited space of his contributions to the Polemic, he refers to Proust, Kafka, Borges, Faulkner, Havel, Sontag, Foucault, Adorno, Akhmatova and 
Dilthey, among others. Together with his use of literary terminology, this makes the following self-portrait problematic. It is taken from “Who Is Doing Harm to True Poetry?” (谁在伤害真正的诗歌?, \#35), published in the July 1999 issue of Beïjing Literature (北京文学) (p69):

I have no high-level degree, I haven't lived in Beijing, that "center" of theory, I haven't read much of the foreigners' lofty words and great wisdom.

This statement is awkward in its differentiation between nonIntellectual and Intellectual as corroborated by an alleged difference of "high-level" and other degrees in tertiary education. As to Xie's own background, at Fujian Normal University he studied with Sun Shaozhen, a veteran champion of the avant-garde who played a major role in the early 1980s debate on Obscure Poetry. In 2006, Xie himself was to become a full professor in the Chinese Department of Zhongshan University.

Contentwise, like Xu Jiang, Xie Youshun makes no groundbreaking contributions to the debate, instead coming across as an admiring disciple who repeats the teachings of Yu Jian. His long article "Poetry Is Advancing" (诗歌在前进, \#96), published in the April 2000 issue of Mountain Flower, contains interesting reflections on colloquial diction in poetry but stands out by a lack of poetry-historical perspective and, again, by the virulence of his style.

Intellectuals such as critic Tang Xiaodu (\#32) and poets Wang Jiaxin (\#51) and Xi Du (\#28) took issue with Popular authors over what may to an outsider appear as just one more ripple in the floodwaters of text generated by the Polemic: specifically, the expression true face (真相), used in the headline of Xie's April 1999 book review. True face means 'true features,' 'true colors,' 'true situation,' and was taken as a grievous insult because it is political jargon, typically used for the exposure of matters arousing moral indignation. Yu Jian, however, would soon enthusiastically elaborate on the image of a true face, resulting in some of the most deafeningly belligerent pages in the Polemic.

\section{The Panfeng Poetry Conference, "Where Words Were Swords," and the Media}

Despite the relaxation of political control in the contemporary period, in literary life in the PRC it is still true that much more can be spoken without fear of censorship than written. Coupled with a continu- 
ing prescriptive streak in scholarship and criticism that is visible in questions of the type Whither Chinese literature? and the frequency of shoulds and oughts in the answers, this adds to the importance of institutionalized, spoken exchange. Since the late 1970s there have been many ambitious conferences on New Poetry where funding from statesanctioned institutions hasn't precluded forays far outside orthodox literary discourse and sometimes near-exclusive attention to the avantgarde. It was at one of these events, held from 16 to 18 April 1999, that the Popular-Intellectual Polemic burst out into the open.

The organizers of the Panfeng poetry conference, so named after the hotel near Beijing where it took place, were the Beijing branch of the Writers' Association, the Contemporary Chamber of the Research Institute for Literature of the Chinese Academy of Social Sciences, the literary journal Beïing Literature and the editorial board of Poetry Exploration. The conference was officially entitled "Turn of the Century: A Seminar on the State of the Art and Theory-Building in Chinese Poetry" (世纪之交: 中国诗歌创作态势与理论建设研讨会). As usual, in addition to scholars and critics, many poets were in attendance. This illustrates the generalization that demarcation lines between the literary and the scholarly, or the creative and the critical, tend to be less clear-cut in China than in many countries in the West.

The Panfeng conference is remembered as a head-on collision between the Popular and the Intellectual. Whether this confrontation was consciously planned, and by whom, is in itself irrelevant to the issues of the Polemic. Suffice it to note that various commentators have emphasized the "strategic" (策略性) behavior of certain participants in the conference and in the Polemic at large. There was much talk of conscious attempts in the run-up to the conference to help the Polemic make media headlines beyond specialist circles, and of phone calls by Popular activists trying to persuade their Intellectual fellow poets and critics to put on a show of fierce, irreconcilable conflict. ${ }^{10}$ Be that as it may, the conference generated enough publicity and collective memory to become a metonym for the entire debate, as witnessed by the fact that this is now remembered by many as “the Panfeng Polemic” (盘峰 论争).

${ }_{10}$ Personal communication on several occasions since 2000, with Tang Xiaodu, Wang Jiaxin, Zang Di and others. 
For the scholarly reader, the June 1999 issue of Poetry Exploration contained an elaborate report on the conference by Zhang Qinghua, entitled "True Dialogue and the Crossing of Swords in Poetry" (一次真 正的诗歌对话与交锋, \#26) and reprinted at the head of a two-part special feature on the Polemic in the July and August issues of Beijing Literature. Zhang's scholarly report was preceded in mid-May by a piece by Tian Yong in the China Youth (中国青年报) daily, called “No 'Wars' for Over Ten Years: The Poets Can't Hold Themselves Back Any Longer” (十几年没 “打仗”: 诗人憋不住了, \#21), later excerpted in the New China Literary Digest (新华文摘) as “A Polemic, Yet Again, on New Poetry's Course of Development” (关于新诗发展方向又起 论争). Tian's original title displays a sensationalism that is typical of much of the newspaper coverage of the Panfeng conference, especially in pieces sympathizing with the Popular cause. The author's quasiobjectivity is belied by slips of the pen and borrowings from Popular polemicists:

The [Intellectual] tendency to make the writing of poetry more and more like knowledge / intellect and abstruse learning is one of the main reasons that present-day poetry's plight is worsening by the day.

In mid-June the China Book Business Newes (中国图书商报) commissioned reviews of Yang Ke's yearbook by Intellectuals Cheng Guangwei (\#27) and Xi Du (\#28), and of Tang Xiaodu's yearbook by Popular author Yi Sha (\#29), which were printed side by side under the headline "What Are Their Quarrels About?" (他们在争什么?). Predictably, all three pieces are devastatingly critical. Cheng accuses Yang Ke of doing harm to the intellectual-cultural spirit of Poetry of the Nineties, seemingly oblivious to the widespread disapproval his use of this phrase had earlier elicited. Xi Du expresses disappointment at the sloppy, irresponsible editorial job that he claims Yang Ke has done. Yi Sha, while recognizing this deficiency, says it is made good by the vitality of Yang's yearbook, in contradistinction to the mediocrity, unoriginality and general lameness he detects in Tang's yearbook. Yi Sha's claim that Tang Xiaodu had publicly questioned the legitimacy of an anthology "edited in the provinces" provoked a fuming letter to the editor by Tang (\#41), published three weeks later and followed up by Tang in another publication late in 2000 (\#111).

Subsequently, on 1 July the fortnightly Literary Theory (文论报) devoted its full second page to the Polemic, carrying articles by Zang 
Di, Shen Qi, Xi Du and Chen Jun. In "Who Is It Has Harmed Poetry of the Nineties” (谁伤害了90年代的诗歌, \#38), critic Shen Qi foregrounds the clamor following the publication, some months earlier, of Yang Ke's yearbook and Shen's own "Square Accounts after the Autumn Harvest-1998: Memorandum on the Chinese Poetry Scene" (秋后算账一1998: 中国诗坛备忘录, \#10), first published in the February issue of Publication Panorama (出版广角). Shen's ostentatious surprise at the full-scale conflict that has emerged is unconvincing. His "Square Accounts" - the expression usually means 'wait until a political movement is over to get even with someone' - is an aggressive attack on Intellectual Writing, naming Xi Chuan, Wang Jiaxin and Zhang Shuguang as its foremost perpetrators. This is how Shen describes Intellectual Writing (p23):

The malpractice of highfalutin, lyrical poetry in a translationist language, full of perplexing images, metaphors copied from elsewhere, ossified ideas as well as a fabricated spirit and unclear character.

He says that Intellectual Writing makes him, a professional poetry reader, "giddy in the head." In "Who Is It," Shen doesn't pull his punches either, depicting the Popular poets as victims of harm done to poetry by the Intellectuals. Chen Jun's "What Poetry Does Not Relate to" (诗歌不与什么相关, \#37) is a sarcastic rejoinder to Xie Youshun's articles, alluding to Xie's "What Does Poetry Relate to?" (\#15), and berating him for his ignorance. Zang Di's contribution to Literary Theory (\#40) was soon reprinted in Beijing Literature and is included in the discussion of that journal's special feature below. Xi Du's "Is Poetry Common Knowledge?" (诗歌是常识吗?, \#39) is an excerpt from his much longer article "Thoughts on Various Issues" (对几个问题的思考, \#24) in Poetry Exploration, also reviewed below. In sum, Literary Theory canvassed the opinions of three Intellectuals and one Popular author. To explain this imbalance, editor Liu Xiangdong later said that he was forced to find a replacement for one of the four originally commissioned pieces at the eleventh hour. ${ }^{11}$

In mid-July, Jing Yi published a critical article in the widely read Beijing Daily (北京日报) entitled “The '99 Poetry Scene: The Battle of the School of 'Popular Writing' and the School of 'Intellectual Writing” (99诗坛：“民间写作” 派与 “知识分子写作” 派之争，\#42).

\footnotetext{
${ }^{11}$ Personal communication, November 2002.
} 
Like Zhang Qinghua's, Jing Yi's assessment of the debate comes across as impartial. She notes the tendency of the Popular camp to abuse the Intellectuals by calling them names like "pseudo-poets" (伪 诗人), “comprador-poets" and “domestic exile poets" (国内流亡诗 人). Like Zhang, Jing Yi wonders how much of the Polemic is really about poetry. She observes that the Panfeng clamor also gave belated expression to Popular frustrations over a March 1998 conference called "Seminar on "Post-New-Tide Poetry" (“后新诗潮” 研讨会) to which major Popular poets such as Yu Jian and Han Dong had apparently not been invited-New Tide Poetry (新诗潮, literally 'new poetry tide') being one of the many names given to the avant-garde over the years. ${ }^{12}$ The difference between these two well-written reports is that, whereas Zhang is inclined to an optimistic view of things, Jing $\mathrm{Yi}$ is disappointed that the debate hasn't yielded any theoretical insights. ${ }^{13}$ She goes on to analyze it in terms of the corporeal (肉身) and the cerebral (头脑), which she links to the Popular and the Intellectual respectively, and concludes by calling the Polemic a tragic incident.

The summer of 1999 saw a flurry of additional publicity. On 26 July the Taiyuan Daily (太原日报) dedicated a full page to the Panfeng conference and its background, featuring articles by Jing Wen, Tang Jin and Wang Wei. Jing Wen is presumably a pseudonym: "Turn-of-theCentury Poetry Polemic" (世纪之交的诗歌论争, \#43) is an abridged version of Zhang Qinghua's report in Poetry Exploration and Beijing Literature. Tang Jin's "Dangerous Trends at the 'Panfeng Conference"" (“盘峰会议”的危险倾向，\#44) is an acerbic piece with orthodox overtones. Tang points out that the conference had little time for textual analysis and criticizes the poets for their self-importance. Wang Wei's "Some Background and Other Things" (背景与其它, \#46) is a record of the words of conference moderators Wu Sijing and Lin Mang, both senior figures on the poetry scene, $\mathrm{Wu}$ as a scholar and Lin as a poet and an editor. Lin Mang observes that at a time when poetry is allegedly in danger of losing its readers, heated debate is a good thing. Wu Sijing calls the Post-New-Tide conference of the previous year a harbinger of divergent trends in criticism which have now come to the surface. According to Wu, in 1998 Xie Mian and Sun Shaozhen expressed skepticism toward current developments in poetry, while

\footnotetext{
12 Huanglin 1998, Shen Qi (\#10): 23.

13 Cf Zhang Qinghua 2002.
} 


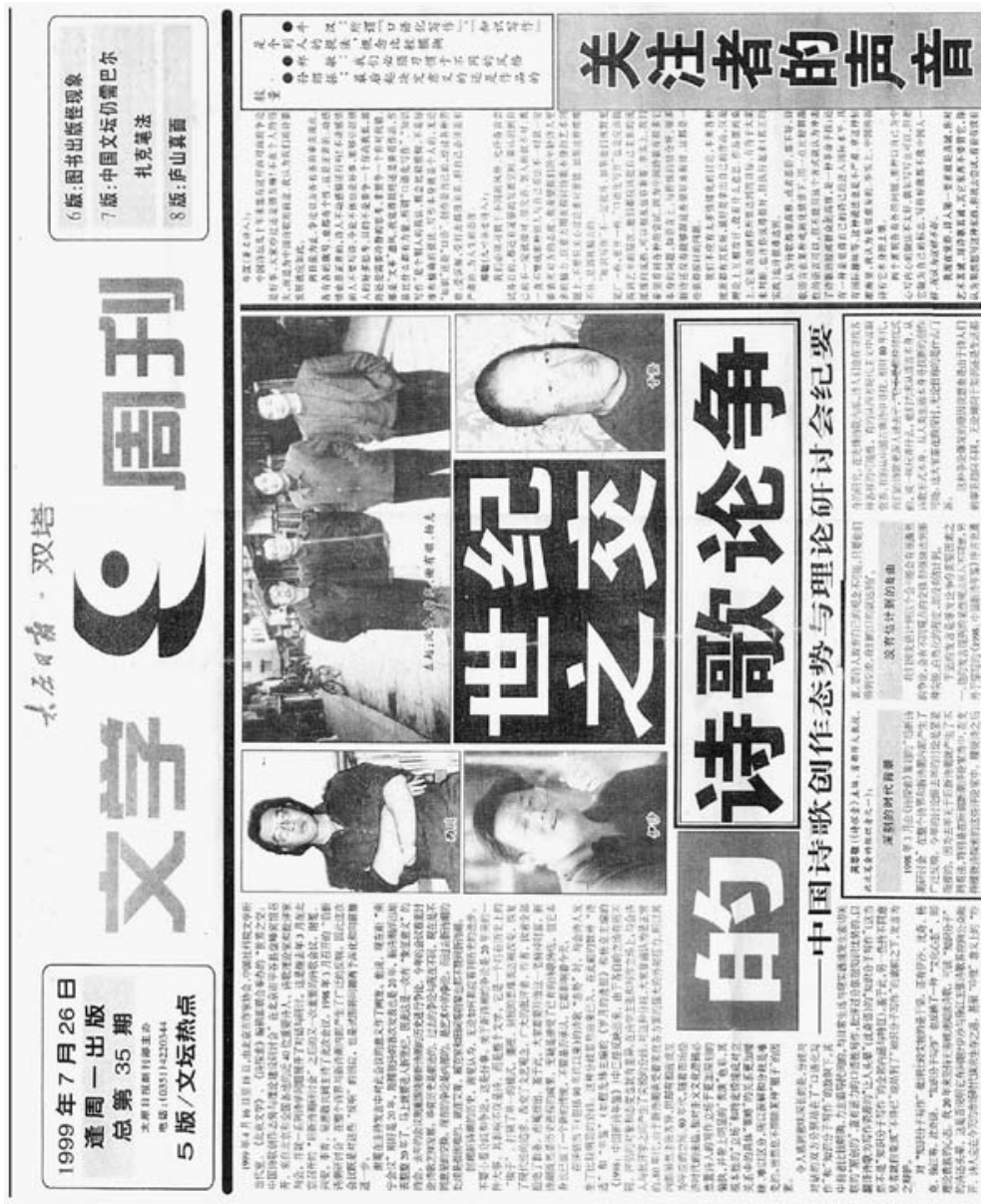

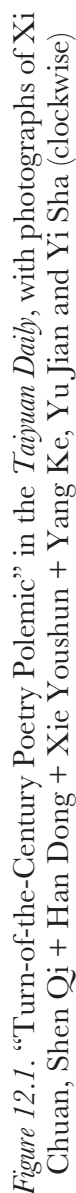


Chen Chao, Tang Xiaodu and Wu Sijing himself were optimistic. Wu says that one of the aims of the Panfeng conference was to provide the said divergence with a platform for discussion.

Wang Wei's other contribution to the Taiyuan Daily, "Voices of Concerned Onlookers" (关注者的声音, \#45), lists comments by grand old poets Niu Han and Zheng Min and by critic Sun Shaozhen. The former two choose their words carefully and avoid taking sides. Sun Shaozhen, by contrast, appears not to be "concerned" at all, opining that the roots of the debate go back to the 1980s and its culmination was hence to be expected sooner or later. He feels certain that in today's China - different from the early 1980s, when Obscure Poetry and "spiritual pollution" came under fire - avant-garde poetry will not become a problem on high-level ideological and political agendas. If the Taiyuan Daily written reports are impartial, its visuals are less so: a single portrait of Intellectual Xi Chuan, next to photographs of Popular authors Yi Sha and Yu Jian, and a group portrait of Shen Qi, Han Dong, Xie Youshun and Yang Ke.

On 31 July the Science Times (科学时报) ran a full-page feature under the headline "Quarrels after the Quarrels of 'Panfeng, Where Words Were Swords" (“盘峰论剑” 是非后的是非), giving the floor to five spokesmen of the Intellectual camp: Wang Jiaxin, Tang Xiaodu, Sun Wenbo, Jiang Hao and Chen Jun. Wang's "More on the 'True Face"" (也谈 “真相”, \#51) is a furious indictment of Yu Jian's distortion of literary history and his deception of those outside the inner circle. In "I See...." (我看到...., \#50), Tang Xiaodu concurs with Wang in accusing the Popular camp of indecent behavior, which may have been taken as a compliment by the accused in light of their self-image as hip, untamed rebels. Sun Wenbo's “The Facts Need Clarification” (事实 必须澄清, \#49) is a powerful piece, less worked up than Wang's and Tang's diatribes. Sun points to inconsistencies and lies in the words of $\mathrm{Yu}$ Jian and others, especially in their accounts of the Panfeng conference. He attributes their exaggerations and improprieties to their insecurity as poets. Sun's article also shows that moralizing and ideologizing diction is by no means limited to the Popular side. In "The Myth of Popular Poetry" (民间诗歌的神话, \#48)Jiang Hao, like Tang Xiaodu, reminds the Popular polemicists of the horror, verbal and otherwise, of the Maoist years, and joins the ranks of those shooting holes in Yu Jian's private brand of argumentative logic. In "Who Does Yu Jian Think He Is Fooling” (于坚愚谁, \#47), Chen Jun decries the 
way in which pure ambition has made the famous Kunming poet degenerate into his present state.

Four weeks later, on 28 August, the Science Times gave four Popular voices an opportunity to respond: Yi Sha, Yu Jian, Xu Jiang and Shen Haobo. The full-page feature's headline runs

Beijing Poets Sheathe Their Swords

Local Bards Now Stretch Their Bowes

If we grant po-ets two syllables, this translation retains the original line length of seven syllables, common in classical Chinese poetry (诗):

北京诗人剑入鞘

外省骚客又张弓

The parallel contrast of Beijing with the provinces (rendered as local) is followed by one of Northern poets 诗人 and Southern bards 骚 客. In this particular context the latter term can also mean something like 'rabble-rousers.' It brings to mind Qu Yuan's «On Encountering Trouble» (离骚) in Songs of the South and an opposition of this ancient "Southern" poetic tradition and a "Northern" tradition represented by the Book of Songs, even though this dichotomy is complex and by no means absolute. ${ }^{14}$ Thus, the headline's choice of words alludes to Chinese literary history to reflect the North-South and central-regional dichotomies put forward by Popular poets and critics.

As for the individual contributions to the Science Times, Yi Sha's "So Who Is It Has Gone Mad?” (究竟谁疯了?, \#60) is an example of Yi's rhetorical talent for the genres of satire and pamphlet. He attacks Xi Chuan (\#33) for having likened Popular activism to an "underworld" of poetry. The opening paragraphs of Yu Jian's "Who Is Producing Discursive Power?” (谁在制造话语权力?, \#61) are hilarious. $\mathrm{Yu}$ wonders how poets can live in a place like Beijing, which he turns into a locus of estrangement from indigenous culture, and suggests that the heated reactions to his writings are probably explained by dog-day temperatures in the capital. In 'Dare Say 'No' to the Poetry Scene” (敢对诗坛说 “不”, \#59) Xu Jiang expresses disappointment in Wang, Tang and other proponents of the Intellectual cause, and offers an account of the Panfeng conference of the type labeled tendentious and deceptive by Intellectuals like Sun Wenbo. In "Let the Polemic

\footnotetext{
${ }^{14}$ Hawkes 1985: 15-28, Hartman 1986: 59-63.
} 
Sink In” (让论争沉下来, \#58), Shen Haobo argues against reconciling words such as those of moderators Lin Mang and Wu Sijing, and notes, not without reason, that poets and critics are dangerously inclined toward establishing mutual admiration societies.

Simultaneous with coverage of the Polemic in newspapers, the literary press, from scholarly publications to those addressing the general public, continued to publish articles by Intellectual and Popular polemicists. The special feature in the July and August issues of Beïing Literature included pieces by Chen Chao, Tang Xiaodu, Xie Youshun, Xi Chuan and Han Dong (in part one), and Yu Jian, Zang Di, Xi Du, Sun Wenbo, Wang Jiaxin, Shen Qi and Hou Ma (in part two), thus maintaining a balance between persuasions. In " $\mathrm{Q} \&$ A: Views on Some Points of Common Knowledge” (问与答: 对几个常识问题的看法, \#30), Chen Chao calls the opposition of Intellectual and Popular a fiction. He finds the charge leveled at the Intellectuals of using "Western language resources" detestable and invalid, because it forces people to take sides - Are you with the West or with China? - and because what matters is not one's raw material but what one does with it. Tang Xiaodu, in “An Open Letter to Mr Xie Youshun” (致谢有顺君的公开 信, \#32), points out the resonance of Maoist literary discourse in Xie's writing, reminding him that the avant-garde took two decades to reach its current state of pluriformity and abundance. He reprimands him for his lack of tolerance and for ideologizing the debate. Xie's "Who Is Doing Harm to True Poetry?" (\#35) in its turn accuses the Intellectuals of behavior called "obstruction" (遮蔽) in Popular discourse, meaning the manipulation of publishing opportunities and public relations of the poetry scene in the interests of one's own clique and with the aim of keeping others out; we will return to this issue in section 2. Xi Chuan's “Contemplation Is More Important Than Abuse” (思考 比谩骂要重要, \#33), its title doubtless reaffirming his Intellectual status in Popular eyes, contains rebuttals directed at Yu Jian, Yi Sha, Xu Jiang and Xie Youshun, dwells on the phenomenon of abusive criticism (骂 or 骂人) in Chinese literary circles and argues for recognition of the fact that intertextuality with foreign texts as well as Chinese is inevitable, and not a bad thing at any rate. Han Dong's "A Time That Supposedly Loves Culture” (附庸风雅的时代, \#31) is a bitter piece focusing on Han's perception of a small number of Intellectual poets, influential since the 1980s, as obstructing the careers of others. Complementary to Han's exposition of the Popular cause, discussed 
separately below, this warrants a long quote. The following passage further illustrates Han's uneasy relationship with "the West" (p74):

As for those who became famous in the 1990s . . . their reading is of the purposeful kind . . . They have in their reading gradually entered into role play. Hence, it is not at all difficult to understand their pathological love of books ... They only read books that they think they have written themselves or could have written themselves, they are only concerned with the lives (or the lifestyles) they think are their own or could have been their own ... They deeply love translated works of foreign literature and deeply love Western literary history . . . prostrating themselves in admiration before so-called masters and giants . . proving themselves familiar with their lives and anecdotes as if enumerating their own household treasures ... All of their inspiration comes from their reading, and their writing style, patterns and forms never exceed that precedence ... Like all collectors and antique lovers they identify absolutely with books, and with a bookish value-judgmental attitude toward thinking and art ... Their most extreme manifestation is if they can produce forgeries with their own hands . . . so that not even a connoisseur could see the traces of those hands. If there is a difference with top collectors and antique lovers, it has to be that our "reader-artists" ultimately fool themselves.

Part two of the Beijing Literature special feature opens with an article by $\mathrm{Yu}$ Jian, to which we will shortly return. Zang Di, in his "Poetry as a Special Kind of Knowledge / Intellect” (诗歌: 作为一种特殊的知识, \#40), emphasizes (p92)

the need to work hard to develop poetry anew toward a form of knowledge / intellect that is independent from science, history, economics, politics, philosophy.

Zang warns that popularizing trends in twentieth-century Chinese literary discourse have turned against innovative poets more than once, cautioning against a repetition of such mechanisms. Xi Du's "A Plea for the Right to Write" (为写作的权力声辩, \#56) - an abridged version of his "Thoughts on Various Issues" (\#24), discussed below-is important in that $\mathrm{Xi}$ Du questions the assumption that Intellectual poetry is divorced from things like daily life, the zeitgeist of its authors' here-and-now and so on. In "On 'Western Language Resources"” (关 于 “西方的语言资源”, \#54), Sun Wenbo berates Yu Jian for mobilizing ethnic and nationalist sentiments, citing Li Bai's Turkish descent as an example of the natural phenomenon of cross-cultural influence. 
Wang Jiaxin's “On 'Intellectual Writing” (关于 “知识分子写作”, \#55) states that

[Intellectual Writing], in a society like China's, first of all demands writing to be independent, oriented toward humanist values, to have a critical spirit; it demands a basic quality and style that have been lacking from modern Chinese poetry for too long.

Notably, the word translated as quality and style (品格) also means 'moral character.' Shen Qi's “What Is 'Intellectual Writing” (何谓 “知识 分子写作”, \#53) holds that critical discourse has generally supported Intellectual Writing and contributed to the obstruction of Popular poetry. Beijing poet Hou Ma rails at the affectations that come with Intellectual poethood in his "The Nineties: The Beginning of Professional Writing by Amateur Poets" (90年代: 业余诗人专业写作的开 始, \#52).

Part two of the Beijing Literature special feature opens with Yu Jian's “Their True Face: On 'Intellectual Writing' and New Tide Poetry Criticism” (真相: 关于 “知识分子写作” 和新潮诗歌批评, \#63). In this piece, Yu's lack of argumentative cogency appears to have been aggravated by drastic editorial cuts, but the article was soon published in full in the September issue of Poetry Exploration. In "Their True Face," which is a declaration of allegiance to Xie Youshun's controversial usage of this phrase, Yu Jian fulminates against Ouyang Jianghe's famous essay "Writing Poetry in China after '89: Indigenous Disposition, the Marks of Middle Age and Being an Intellectual." ${ }^{15}$ Yu traces a monopolizing and obstructionist spirit informing publications such as Cheng Guangwei's Portrait to the early 1990s and blames poetry critics for having sold out to the Intellectuals. Earlier having charged the Intellectuals with ideologizing poetry through "hard" language and identified Intellectual discourse with orthodoxy by contrasting it with the Popular, he reaffirms this identification by claiming that attacks on the Third Generation-meaning Earthly authors from the mid-1980s onward - came first from orthodox and then from Intellectual quarters. As evidence, he cites an attack on the avant-garde by orthodox critic Zhang Hongming in the Literature $\mathcal{E}^{\circ}$ Art Review (文艺报) in 1990, entitled “New Tide Poetry”Unmasked” (对“新诗 潮” 的透视). ${ }^{16}$ Precisely because of Yu Jian's active dissociation from

\footnotetext{
15 Ouyang 1993a.

16 Zhang Hongming 1990.
} 
orthodoxy, one cannot but notice that the images of a true face and of unmasking - literally, 'seeing through' (透视) — are strikingly similar. What's more, the structure of Yu Jian's piece is near-identical to that of Zhang's: a number of central, rhetorical questions in bold type, each followed by a predictable answer, dished out in an irreconcilable tone.

Content aside, one of the reasons that the Popular camp held the upper hand in the Polemic from start to finish was the sheer productivity of authors such as Yu Jian, Yi Sha and Xu Jiang. Another was their readiness to be rude and, quite simply, shout down their Intellectual adversaries. This point is illustrated by the breathless sentence length in the concluding paragraphs of Yu's "Their True Face" (p47-48):

Poets from the provinces who insist on the Popular standpoint, on Poets' Writing, on the Chinese experience and on poetry's freedom, independence, originality and democratic spirit, who are non-ideological and position themselves in the margin [on the one hand], and hegemonic critics who use the geographical dominance of the cultural and political center that is Beijing to attempt, in line with historical practice, to make the discourse of power once more incorporate a poetry that has regained independence and dignity since the Eighties, and to establish an overweening type of order in the poetry scene [on the other] - theirs is an irreconcilable relationship of water and fire, and its true face is now there for all to see.

Superior poets making their own rut, immersed in writing in the vast lands of China's provinces, without critics to wave banners and shout battle cries for them, far from the convenience of international connections to be found in Beijing, who have relied only on creative and extraordinary poetic texts to establish within the bronze walls and iron ramparts of China's poetry scene the dignity of poetry and its individual charm [on the one hand], and the "Intellectual Writing" line of thought of make-believe, mediocre poets who are really readers of Western poetry and literary-artistic theory, who count on the discourse of power and the critics' lavish praise and who would cease to exist without this discourse and this praise [on the other] - theirs is a clear distinction of good and bad, and its true face is now there for all to see.

The Beijing part of the New Tide poetry criticism that relied on the actual achievements of excellent Third Generation works to make a name for itself in the great Eighties has now thoroughly betrayed the tolerance toward minority and alternative writing of a poetry criticism resurrected in that great time filled with the spirit of liberalism: a non-moral, non-ideological, free, independent, objective, fair professional spirit and text-oriented scholarly standpoint have pitifully turned into "Intellectual 
Writing" - spokespeople for an "inner circle" have no way any longer of upholding their make-believe "fairness and authority," their attitude toward poetry and poets is nothing but "Prosper those who are with us, perish those who are against us," they dare, utterly evil, besiege the author - a poet, and this goes to show that these "New Tide Poetry critics" have never respected poetry. Their true face is now there for all to see.

"Besieging the author" refers to Popular accounts of the Panfeng conference claiming that several Intellectual authors had physically laid siege to Yu Jian or Yang Ke. These were dismissed by their alleged besiegers.

Both specialized and general media would seem to have worked to the advantage of the Popular camp. First, if Cheng Guangwei's appropriation of the concept of Poetry of the Nineties was objectionable to many, it was not a consciously polemical maneuver. Starting with Yang Ke's yearbook and Yu Jian's "The Light," however, the Popular response was just that. As such the Popular side dealt the first blow and a few more, and it appears to have been more active in seeking publicity throughout. Second, as far as the broad reception of polemical discourse is concerned, this naturally rewards anti-elitist sentiment and the shock value of invective. Popular contributions to the debate tended to be more spectacular and suited to the sensationalism inherent in most media. In the rest of 1999 and 2000 the Popular side continued to dominate the debate.

Friends in Letters, for instance, published two more eye-catching pieces. One, in the July issue, is "Has Poetry Really Lost Its Readers?" (诗歌真的失去了读者吗, \#34) by Xiangzi, widely believed to be a pseudonym of $\mathrm{Yu}$ Jian. The article does contain argumentative, terminological and linguistic clues to that effect. Xiangzi reassures the reader that only bad-Intellectual - poetry has lost its readers. The article is rare in that it supports the Popular cause but acknowledges that good-Popular-poetry is by nature a marginal phenomenon and cannot be appreciated by many.

In addition, in November 1999 Friends in Letters featured Yi Sha's long article "End of the Century: Why the Poets Are Going to War" (世纪末: 诗人为何要打仗, \#75), which simultaneously appeared in Poetry Reference as "Two Questions against One Background: The Panfeng Poetry Conference as I Experienced It” (两个问题和一个背景: 我所经历的盘峰诗会). When reprinted in Yang Ke's next yearbook, the one covering 1999, it was still entitled "End of the Century," which 
does justice to the article's scope and ambition. It contains Yi Sha's shamelessly biased report on who said and did what at the conference, and his presentation of the event as the outcome of an overall schism in poetry and criticism dating back to the 1980s. Yi looks back on Haizi's suicide as a defining moment and a rare opportunity for the Intellectual camp to maneuver its aesthetics into a position of privilege on the poetry scene, so that (p80)

a rhetorical conspiracy made of metaphor made muddle-headed Western sinologists think they truly dared confront Chinese reality.

True enough, Haizi's posthumous mythification has been disproportionate. Still, Yu Jian's, Xu Jiang's, Yi Sha's and other Popular voices' studied irreverence toward his life, work and death strike one as strategically inspired breaches of a taboo, carried out for sheer effect. Otherwise, it is hard to see the relevance of comments like this, made by $\mathrm{Yu}$ Jian (\#36) in the July 1999 issue of Hunan Literature (湖南文学) (p75):

Apparently, Haizi couldn't even ride a bicycle but still thought of himself as a king among men who hadn't been given the position due to him, and so he went and killed himself.

Yi Sha is of the opinion that when poets hold a conference this is not to exchange views but to exhibit their temperament, and his style in "End of the Century" and elsewhere indicates that this also applies to written presentations. His promise of objectivity and fairness rings accordingly hollow, if it isn't intended as a joke to begin with. Yi's self-contradictions alternate with wickedly clever arguments. He turns Wang Jiaxin's employment of Cultural Revolution terminology against him, as if Wang were not citing such terminology to illustrate the Popular resurrection of Maoist discourse. Yi's castigations of the Intellectuals contain macho, sexist and misogynist comments, such as when he associates the phrase Middle-Aged Writing (中年写作), used by poets like Ouyang Jianghe and Xiao Kaiyu, with sexual impotence, ${ }^{17}$ and when he reports on his own speech at the conference (p79):

So-called "Intellectual Writing" makes me think of the notion of "Women's Literature." What I feel about "Women's Literature" equally applies to "Intellectual Writing": as a man, I hardly ever think about what it is grows in the crotch of my pants, and I definitely don't need to go trumpeting it around.

17 Ouyang 1993a: passim, Xiao Kaiyu 1997a: 226. 
In addition to Friends in Letters, two other publications that consistently supported the Popular side were the Social Science New Book Catalog (社 科新书目) and Poetry Reference. Especially in the spring of 2000, the weekly Catalog gave Popular voices (\#91, 93, 94, 95, 98, 99, 105) much more and, judging by the editor's notes (\#92), much more sympathetic exposure than Intellectual ones (\#97, 100). Issues 14/15 and 16 of Poetry Reference, published in November 1999 and July 2000, contained articles earlier featured elsewhere as well as contributions written especially for this long-standing unofficial journal. In 1999 its special feature called “Journal within a Journal" (刊中刊) pays lip service to impartiality by reprinting Intellectuals Wang Jiaxin and Zhang Shuguang side to side with Popular authors Yu Jian, Yi Sha, Xu Jiang, Yang Ke, Song Xiaoxian and Shen Haobo, but the loyalties of editor Zhongdao are explicitly of the Popular kind. In the 2000 edition all polemical entries in the "Journal in a Journal" are of Popular persuasion. Poet and painter Yan Li's "Preaching and Packaging" (说 教和包装, \#109) was written in 1997, long before the Polemic had begun, and Yan discusses a type of intellectual — overseas, dissidentwith political policy-making aspirations that has nothing to do with the Intellectual poets. Its mind-boggling inclusion may be explained by Yan's pejorative use of the word intellectual, grist to the editor's mill and evidence of his strategic motivation.

If publicity beyond specialist and general literary circles was by and large conducive to Popular image-building, it wasn't entirely one-sided. Ding Mang's "The True Nature of the So-Called 'Popular Standpoint” (所谓 “民间立场” 的实质, \#69), published in the China Times, manages to maintain critical distance while tearing Popular theorizing to pieces and charging it with intolerance and an attempt at monopolizing avant-garde status. As for specialized literary and literary-critical journals, Mountain Flower and Grand Master published Intellectual and Popular contributions equitably - as did Poetry Exploration, in by far the greatest number of pages and the richest variety of content.

The present chapter gives the Popular more space than the Intellectual. This reflects the sheer size of the two camps' respective output and the fact that the Popular side by and large kept the initiative in 1998 and 1999. Intellectual rejoinders, moreover, warded off or deconstructed Popular arguments but generally stopped short of attacking Popular poetry in their turn, and occasionally hinted that reacting 
to Popular invective was a waste of words. ${ }^{18}$ As such, the Intellectual role after the outbreak of the Polemic was predominantly defensive. Then again, in the Popular view - according to Yu Jian (\#63), for example - an Intellectual offensive and its sidelining of the Popular cause had been quietly operational since the late 1980s, propelled by authors such as Xi Chuan, Tang Xiaodu, Wang Jiaxin, Chen Chao, Ouyang Jianghe, Zang Di and Cheng Guangwei. We will now review some of the said Intellectual rejoinders before discussing a remarkable essay by Popular author Han Dong, and outlining how the Polemic more or less came to an end in mid-2000.

\section{Wang Fiaxin's Staunch Defense: "A Poet Is Always an Intellectual"}

Measured by hostile and partisan comments alike and by the quality and quantity of his critical output during the Polemic, the most prominent of the Intellectuals was Wang Jiaxin. Of his several contributions, the most substantial are "Intellectual Writing, or 'In Dedication to a Limitless Minority” (知识分子写作, 或曰 “献给无限的少数人”, \#23) and “Start from a Misty Drizzle" (从一种蒙蒙细雨开始, \#86). "Intellectual Writing" is the written version of Wang's address at the Panfeng conference. With some modifications, the article appeared in the June issue of Poetry Exploration and the August issue of Grand Master. It was also included in Wang Jiaxin and Sun Wenbo's Chinese Poetry: Memorandum for the Nineties (中国诗歌: 九十年代备忘录, 2000) (\#85), another controversial anthology, to which we will turn in the final paragraphs of this section. "Start from a Misty Drizzle" is the introduction to this anthology, but the December 1999 issue of Poetry Exploration published the essay as a stand-alone article one month prior to the book's actual release. In dedication to a limitless minority is a phrase taken from the work of Zhai Yongming, implicitly claiming the allegiance of contemporary China's most famous woman poet, whereas Zhai herself had given no sign of taking sides. Start from a misty drizzle comes from an early poem by Xi Chuan, whose mobilization in support of the Intellectual cause entails no such problems. Both pieces are well written and forceful, and contain cogently argued passages with critical distance from the battlefield. In light of the attacks Wang had endured since 1998, this is no small feat.

18 E.g. Cheng Guangwei (\#27). 
"Intellectual Writing, or "In Dedication to a Limitless Minority" is a rebuttal to accusations from the Popular camp in which Wang primarily responds to Yu Jian and Xie Youshun. He argues convincingly that Yu Jian's creative output, particularly his «File 0», is a far cry from meeting the criteria for good poetry as laid out in Popular polemical discourse. In addition, he questions Yu's portrayal of poets of the Chinese language, cited above. Wang points out that $\mathrm{Yu}$ is guilty of the crime of "connecting" with the West as much as anyone else (p48-49):

Aren't Chinese poets writing in Chinese, and not in English? Is this something that needs to be advertised? Can it be true that the translation of works by Chinese poets into foreign languages doesn't add to the glory of Chinese poetry and becomes a poet's crime instead? How is it that Yu Jian, who himself has also hinted at and indeed flaunted the fact that foreigners place orders for his work, now poses as "refusing to connect"? In plain words, all of this is but strategic behavior. All of this is but in order to ride the rising tide of nationalism ... All of this is but to show: while the others are all busy connecting with the West, I myself am the only one working to restore the dignity of the Chinese language. Of course, to restore the dignity of the Chinese language is Chinese poets' mission throughout their lives - but how to go about that? By false, inflated, hollow words? By denouncing the languages of other nations?

Wang questions the dichotomies that underlie Popular discourse, and most of all the confluence of these dichotomies in an overall opposition of Popular and Intellectual. In a simple aphorism, he submits (p4041):

Of course an intellectual is not the same thing as a poet, but a poet is always an intellectual.

According to Wang, all those embroiled in the Polemic are intellectuals, in a country where that category of people was made to suffer through large parts of the twentieth century. He laments that they have now become antagonists, instead of allies in the face of common enemies such as official cultural policy and the rampant commercialization of Chinese life. He also rejects the parallel oppositions of North and South and of the foreign and the Chinese, drawing attention to the complexity and multi-directionality of things like literary influence, intertextuality and intercultural relations.

As noted, a little over a month after Wang Jiaxin's "Start from a Misty Drizzle" had appeared in Poetry Reference and Poetry Exploration, 
it served as the introduction to Wang and Sun's Chinese Poetry, which came out in January 2000. Wang makes no attempt to appear impartial; the essay's journal publication aside, we will shortly consider the results of his partiality - as editor - for the anthology as a whole. He acknowledges that during the early and mid-1980s Chinese poets sometimes uncritically absorbed and imitated Western literature, theory and criticism, perhaps to make up for the spiritual famine of the Cultural Revolution; but he rightly observes that since the late 1980s Chinese poetry's interaction with the West has been the subject of critical reevaluation, and that this is visible in poetry by various Intellectuals. As open-minded as Wang is when discussing such developments, as rigid is he when reiterating Cheng Guangwei's appropriation of the notion of Poetry of the Nineties to denote but one of many possible literary persuasions rather than a non-judgmental, chronological category. Another weakness is that, contradicting Wang's habitual remarks on the "bitter struggle" in which he sees poetry as forever engaged, his essay breathes a complacent sense of the end of history. With hindsight, previous trends are shown to have led inevitably to $(\mathrm{p} 10-11)^{19}$

independent intellectual individual writing.

That is: to the ultimate poetry - of the kind to which Wang Jiaxin subscribes. But Wang is not the only one who feels that the poetry of his preference is the only right poetry, not to say the necessary poetry, for contemporary China. The same holds for various authors from the Popular camp, Yu Jian (\#14) most of all.

\section{Other Intellectual Rejoinders: Xi Du and Cheng Guangwei}

$\mathrm{Xi} \mathrm{Du}$ was another impassioned and productive defender of the Intellectual cause (\#24, 28, 39, 56). His "Thoughts on Various Issues" (\#24), first published in the June 1999 issue of Poetry Exploration and excerpted as "Is Poetry Common Knowledge?" for the special feature in Literary Theory, also appeared under the more apposite title "Challenging Some of Yu Jian's Poetical Propositions” (对于坚几个诗学命题 的质疑) in the July issue of Mountain Flower. Xi Du tends to get carried away when he speaks out in support of Intellectual Writing, but he ef-

19 The page reference is to the article's publication in Chinese Poetry. Cf note 3. 
fectively puts his finger on the flaws in Yu Jian's allegations. He argues that a linkage of poetry and the zeitgeist is by no means the exclusive prerogative of the Popular. As regards the opposition of things foreign and Chinese, language resources and other, he diagnoses Popular xenophobia as an expression of insecurity. With frequent reference to Shao Jian's “So What Is It You Want from Poetry?” (你到底要求诗 干什么?, \#9), an article commissioned for Yang Ke's first yearbook that turned out to be highly critical of Popular discourse, Xi Du rejects Yu Jian's usage of popular. He notes that as recently as the 1980s, Popular authors who now affiliate themselves with Tang and Song poetry still claimed to reject Chinese cultural tradition in its entirety.

After the frenzied polemicizing in the summer of 1999, Cheng Guangwei responded to his various critics in the October 1999 issue of Grand Master. His "New Poetry Runs through History's Veins: In Response to A Polemic" (新诗在历史脉络之中: 对一场论争的回答, \#66) is balanced and level-headed. If the article fails to enervate the charge of Cheng's partiality, it does put Popular discourse in a useful historical perspective. Cheng says that important parts of the debate can be subsumed under recurrent issues in the history of China's New Poetry. He associates the present Popular activism with certain aspects of "leftist" zealotry from the 1920s through to the 1970s. In a nutshell (p191):

Problems that occurred earlier in history but have never been solved very well have now been refined, on the suitable occasion that was constituted by the 1990s. [The Popular camp] uses a separation of the poet and the people to derive an opposition of a so-called "Popular standpoint" and "Intellectual Writing"; it makes the development of New Poetry and foreign influence, a well-known issue in the history of New Poetry from the start, sound like the shifting of allegiances to "Western language resources"; it attempts to move poetical problems into the realm of politics and nationalism. In truth, all this leads to the pitfall of cultural fundamentalism, of turning criticism into personal vendettas and something quite out of proportion.

Cheng also dwells on matters such as the complexity of literary influence, the interaction of modernity and ethnicity in twentieth-century poetry and the perpetual debate on the "difficulty" or "incomprehensibility" of certain types of poetry. He sees Popular discourse as an instance of the cultural radicalism that has manifested itself at various times and places in modern China. 
Han Dong's Begeisterung: "Abandoning the Arena of Power"

Be they poets, novelists, critics, scholars, journalists or politicians, Chinese authors are astoundingly prolific and the speed at which they produce books is both exciting and worrisome. He Xiaozhu's Selected Chinese Poems of 1999 (1999中国诗年选, \#78) bears testimony to this side of Chinese graphomania. The editorial committee of this anthology set to work in June 1999 and must have finished in October or so, for the book appeared in December of the year it claims to cover. Then again, it is called a selection of poetry, and as such under no obligation of completeness or representativeness. The editor's postscript (\#79) emphasizes this point, but with an eye to literary persuasion not calendar chronology. He Xiaozhu frankly relates how in spite of admonitions by several poets, he hasn't undertaken to be objective or fair and is partial to the Popular point of view. The order of poets included was determined by drawing lots, with the exception of Xiao An and Sheng Xing, whose pole positions are in explicit homage to the quality of their work.

Amid the accumulation of metatext that is the present chapter, let's read another poem for a change, as a counterpart to Zhang Shuguang's "A Portrait of Years Gone By», cited in the first pages of this section. As we have seen, Zhang's «Portrait» opens an anthology shaped by a particular literary preference. So does this poem by Xiao An (p19):

«Mental Patients

what must you do to walk out of here

tilt your head

a bit more to the right

set your hands in the correct position

confused person

keen appearance in the glass

we've no way to tidy up your brain

to wash you cleaner

you may be the best-looking

and the most complete

but anywhere and everywhere

you're always in such disorder

and whether you're called xiao li or ping'er

all we can do is call you xiao li or ping'er 
you come home

through the streets

with a sign that's been on your body

ever since you were born

you love bananas

and you hate apples

We need no detailed analysis of «Portrait» or «Mental Patient» (精神 病者) to observe considerable differences between the two texts, the figureheads of Intellectual and Popular flagship books respectively - in subject matter, tone, form and overall experience. But let's return to our metatextual business and examine a final, substantial contribution to the Polemic.

Han Dong's “On the Popular” (论民间, \#77)- he often uses 民 间 as a noun phrase - is the introduction to He's Selected Chinese Poems. The tone of "On the Popular" is reminiscent of "A Time That Supposedly Loves Culture," Han's article in the Beijing Literature special feature of the previous summer: not quite as bitter but equally heavy, with a penchant for moralizing and abstractions of the sort we encountered in chapter Eleven. Whereas in "A Time" Han scolds Intellectual Writing, "On the Popular" is a much more constructive undertaking. The essay is divided into fourteen sections marked by subheadings. Some are rhetorical questions predictably answered in the negative (p1, 6, 10):

Is the Popular a Fiction?

Has the Popular Accomplished Its Mission?

Does the Popular Cancel Out the Individual?

Han includes a short history of the Popular. Here, the term cannot but be read in the institutional sense of 'published outside state control.' Like Yu Jian (\#14), Han traces Popular poetry's genealogy through a number of unofficial publications, back to Today. The importance of unofficial status as a criterion for the Popular is clear in this passage from the section entitled "The Popular in the Nineties" (p8):

Some poets who come from the Popular as it existed in the Eighties have now set foot in the mainstream poetry scene, publishing their poetry in official collections, getting public reviews, making regular appearances in all kinds of media, craving to take part in foreign sinological conferences - they have knowingly divorced themselves from the Popular way. 
One immediately thinks of the impressive track record of official publications, public reviews, media appearances and foreign conference attendance of prominent Popular poet and theorizer Yu Jian-whom Han Dong doesn't mention a single time. Are we to take this as evidence of Yu's eviction from the Popular ranks, at least in Han's book? Also, if it seems reasonable to assume that Han sees himself as a Popular poet, we should note that a first official collection of his poetry had in fact come out as early as 1992 - and that this was to be followed in 2002 by a major, official survey collection of his work as well as the first ten volumes in the Epoch Poetry Series of which Han was editor, including books by authors associated with the unofficial journals Them and Not-Not who had no previous official book publications to their name. ${ }^{20}$ Does this mean that Han Dong and the Epoch authors set foot in the mainstream poetry scene, too? If so, how tenable are Han's views on the Popular any longer?

Han Dong particularly disapproves of poets entering mainstream discourse for the wrong reasons, even if it be - in his two examplesthrough no fault of their own. With some justification, he holds that Haizi and $\mathrm{Gu}$ Cheng became martyrs or heroes of poetry in broad public view because they killed themselves, not primarily through the merits of their writing. He risks invalidating this point when he himself invokes as exemplary for the Popular cause two authors who died before their time and one whose saintly status is closely connected to his mental illness: Hu Kuan, Wang Xiaobo and Shizhi. This bespeaks the very image of poethood that has contributed so much to Haizi's thanatography - to which Popular, demystifying and more generally Earthly authors should in theory not subscribe.

As noted in chapter Eleven, according to Han Dong the Popular inherently resists the influence of the three "big beasts" of the System, the Market and the West, with big beast denoting the expansive corruption of an original, authentic category. Han finds the Popular itself inherently incapable of becoming a big beast in its turn. Its standpoint is characterized by $(\mathrm{p} 2)$

an independent spirit and free creation.

20 Han 1992a and 2002. 
Han proclaims an undisguised mission statement, making clear that the Popular has a vocation which reaches far beyond a simple literary preference (p8):

The Popular mission is to safeguard literature, and to ensure that in an age that is growing more materialistic by the day and honors the balance of power as its only standard, literature gets a chance to survive and develop; and to protect the free spirit of art and its capacity for creation.

As a whole the essay is impressive in its Begeisterung. To Han Dong, the Popular appears to be rather like a way of life, a worldview or indeed a religion, and at the very least part of the vision of poetry as a sacred cause that characterizes his explicit poetics throughout. Leading up to a brief, final section on the future of the Popular, as opposed to what he calls the pseudo-Popular (伪民间), Han concludes (p17):

The Popular in its true form means: (1) abandoning the arena of power, and operating in unknown, dark and mute places; (2) the womb of the independent spirit and the vortex of free creation, where what is upheld is talent, steadfast character and a sensitive soul; (3) the necessary, unyielding struggle that is carried out in order to protect the survival of literature and art, in order to protect their expression and the right to write (not the power to write).

The highfalutin, moralizing tone of "On the Popular" comes in sharp contrast with the Colloquial Poetry for which Han is famous, but it blends well into the register established by other central contributors to the Polemic reviewed above: Cheng Guangwei, Yu Jian, Wang Jiaxin.

\section{$A$ Sense of Closure: The End of the Polemic}

In the first half of 2000 many publications still addressed the opposition of the Popular and the Intellectual: again, mostly from the Popular point of view. In March, for instance, the Social Science New Book Catalog reserved yet another full page for blatantly partial, Popular coverage of the Polemic, under the headline "Poetry Scene Explodes into Warfare Yet Again” (诗坛再次爆发战争, \#92, 93, 94, 95), and in May it ran a special feature entitled "Reflections on the First Anniversary of the “Panfeng Polemic” (“盘峰论争”: 周年反思专版, \#97, 98, 99, 100) that gave each camp its own page. By and large, however, these publications repeated or rehashed things that had been said before. Some authors began to take a retrospective stance, Shen Qi (\#101) and Xu 
Jiang (\#108) even hinting at possibilities for reconciliation, saying that this was in the interests of Chinese poetry as a whole and invoking the beginning of a new century as an opportunity for a fresh start.

Viewed in this light, the unabashed partiality of He Xiaozhu's Selected Chinese Poems emanates a sense of closure, reflecting the stalemate in which the two camps now found themselves. The same goes for Chinese Poetry: Memorandum for the Nineties (\#85), the above-mentioned collection of essays edited by Wang Jiaxin and Sun Wenbo, with the editors disdaining to look beyond their own literary loyalties and stubbornly reenacting Cheng Guangwei's appropriation of a chronological category for a particular literary persuasion. Following "Start from a Misty Drizzle," Wang's introduction, the collection includes some forty critical articles from the 1990s. It is a strictly Intellectual, one-sided selection of material, with a few outsiders to the Polemic thrown in for good measure: mostly commentators who are neutrally critical of Popular discourse, such as Zhou Zan (\#88), Yang Xiaobin (\#73), Geng Zhanchun (\#6, 76) and Jiang Tao (\#62). The editorial policy of Chinese Poetry implies that Popular contributions need not be regarded as anything more than transient fashions of the day. This impression is maintained throughout the book's appendices. The first of these contains the "Annals of Poetry of the Nineties" (90年代诗 歌纪事) by Zi An, previously published in Mountain Flower under the author's customary name of Wang Jiaxin (\#67). This was immediately attacked for its partiality by Yi Sha in "Wang Jiaxin's Forged Records of the Historian" (王家新伪史记, \#87) in the January 2000 issue of Friends in Letters, and later by Xu Jiang in "Eyes Turned Green" (眼睛 绿了, \#108) in the 2000 issue of Poetry Reference. The second and third appendix in Chinese Poetry are a discussion of 1990s poetical terminology by Chen Jun and an index to theoretical and critical essays and essay collections from the 1990s by Liu Fuchun and Zi An / Wang Jiaxin. All this makes for a bizarre, complete absence in Chinese Poetry of those considered to be formidable enemies - Yu Jian, Yi Sha, Xie Youshun and so on-judging by the unforgiving way several of the book's contributors take them to task. For Popular poetry and its immediate forebears, this is not a memorandum but an oblitterandum instead. When asked about the exclusion of Popular contributors, Wang Jiaxin at first called the authors in question uncooperative, and then added that he hadn't bothered to contact them. ${ }^{21}$

${ }^{21}$ Personal communication, August 2000. 
In June 2000 Yang Ke published the 1999 Yearbook of China's Nerw Poetry (1999中国新诗年鉴, \#102), keeping a promise to make the Yearbook an annual production. While publications such as the Social Science New Book Catalog, Poetry Exploration and Poetry Reference would continue to carry provocative articles by Popular and Intellectual authors, the appearance of Yang's second yearbook can arguably be seen as the public conclusion to the Polemic. In line with Yang Ke's style of public relations throughout (e.g. \#82), the 1999 Yearbook makes some superficial concessions to impartiality in its choice of poetry and criticism, but no more than that. Here is a final quotation from Xie Youshun's aggressive introduction to the anthology, pre-published in Mountain Flower as "Poetry Is Advancing" (\#96) (p76):

Let poetry be clearly distinguished from non-poetry, truth from lies, creation from imitation, contemplation of the West from the blinkered following of Western masters, dignified writing from the worship of knowledge / intellect, lively speech from reticence vis-à-vis existence, plain words from incomprehensible prattle, the soul's presence from a would-be profound "complex art of poetry," sensitive people from rigidified intellectuals.

As the last quotation in this critical inventory of the sources, Xie's words serve to reaffirm the seriousness of the Polemic and the alarming echo of Maoist literary discourse.

\section{What Was at Stake?}

The Polemic was ignited by Cheng Guangwei's appropriation of the full breadth of the 1990s for a poetry representing but one of several important trends. Authors who united under the Popular flag felt this to be a flagrant instance of what they called the obstruction of their art. It is impossible to verify whether Intellectually inclined poets and critics had actually blocked exposure of other poetries than their own for years on end, consciously or otherwise - and it is easy to verify that no such thing ever happened to, say, Yu Jian or Yi Sha, as a glance at their publication record will show. Then again, for what it's worth, allegations of obstruction in previous years are not made any less likely by Wang Jiaxin and Sun Wenbo's Chinese Poetry as another key Intellectual publication in which Popular authors were given short shrift, even if we take into account that this book was produced when the Polemic was already running at full steam. In any case, from the Popular per- 
spective, the obstruction of one type of poetry or the occupation of the scene by another were not merely detonators or catalysts, but among the root causes of the conflict.

Throughout the Polemic the distinction between authors and texts was blurred. Thus, the indictment of Cheng Guangwei's selection of authors in Portrait seamlessly led to the tendentious dichotomies that we have reviewed, together creating an opposition of the Intellectual and the Popular. This was put forward as representing an opposition of two types of poetry. In itself, as I have argued throughout this study, the avant-garde can perfectly well be viewed as a broad spectrum contained within the outer limits of two divergent aesthetics, and textual analysis and interpretation conducted within such a framework and focused on typically Popular or Intellectual aesthetics yield equally divergent poetics. But as observed above, aside from vague and unsubstantiated mutual accusations, the Polemic had little time for poetry per se.

The genre of polemics has an inherent right to some unreasonableness. Still, this near-complete neglect of supposedly central subject matter is astonishing, all the more so because an opposition of two types of poetry cannot even be maintained on the basis of the explicit poetics found in the polemicists' writings. On the contrary, they display some notable similarities. Take, for example, Intellectual Tang Xiaodu's claim, in both the foreword and the postscript to his yearbook (\#19, 18), to occupying a Popular standpoint (民间立场). These exact words are also the shortest, best-known summary of the poetics proclaimed by Yu Jian in the introduction to Yang Ke's first yearbook, which reprints the phrase as an article of faith on one of the inside cover pages $(\# 14,12)$, henceforth giving it the status of an antiIntellectual slogan. Or take Cheng Guangwei's (\#1) invocation of one of his favorite poets, Xiao Kaiyu, as saying (p5):

Writing shouldn't merely hinge on one's social ambitions, but rather on "material" from politics, economics, love and indeed current affairs and everyday life, it should plant itself firmly in its cultural context.

For all we know, this could be Yu Jian or Xie Youshun talking. Or take discontent with the damage done to poetry by political ideology and commercialization, regularly expressed by Intellectual and $\mathrm{Popu}-$ lar voices alike, with a shared penchant for moralizing - and they were no extras, either, but key players like Wang Jiaxin and Han Dong. A fi- 
nal example of explicit-poetical consistency across the board is Cheng Guangwei's description of the Intellectual creative author as having independent views and an independent position, and Han Dong's typification of the Popular as signaling an independent spirit and free artistic creation.

At this point we may turn to author personalities to help explain what the Polemic was all about, as Leo Ou-fan Lee has done for modern Chinese literary battles in the $1920 \mathrm{~s} .{ }^{22}$ Geographical-cultural dividing lines between authors were put forth by the Popular camp: (i) the Intellectual capital versus the Popular provinces, (ii) the Intellectual North versus the Popular South and (iii) Intellectual Westernization versus Popular Chineseness. All three are each rhetorically smooth and factually problematic. (i) Zhang Shuguang, for instance, labeled a prominent member of the Intellectual camp, has always lived in Harbin, and Popular firebrand Shen Haobo only began to write after he had entered university - in Beijing, where he has remained ever since. (ii) If, in addition to their current whereabouts, we take into account poets' and critics' provenance and their formative years, the list of mismatches becomes much longer. Intellectuals Cheng Guangwei, Wang Jiaxin, Tang Xiaodu, Sun Wenbo and Ouyang Jianghe are all Southerners who moved to Beijing later in life, and Chen Dongdong is a Shanghai resident to this day. (iii) Complicated though things like literary influence and intertextuality may be, it is demonstrably untrue - as is evident from the poetry that most polemicists didn't deign to discuss - that the Popular poets reject or mistrust the West. Why should they, anyway? Conversely, it is equally untrue that the Intellectuals blindly embrace the West.

Incidentally, even if Chinese poets look to the West or anywhere beyond an indigenous frame of reference, a considerable measure of Chineseness is guaranteed as long as they write in Chinese. Language, both the abstraction and its varied manifestations throughout the world, is rather more than a simple tool for dressing up some kind of independent, unchanging content, and poetry is the art of language. Before getting into all that and recalling the discussion of Chineseness in chapter One, one might ask a question whose long history doesn't detract from its relevance today. Why should poetry written by Chi-

\footnotetext{
${ }^{22}$ Lee (Leo Ou-fan) 1973: 19-27.
} 
nese people in the Chinese language have to be Chinese beyond these two features?

Then again, if geographical-cultural dividing lines are questionable, they are probably more than just the figments of a bellicose imagination, especially the dividing line between the capital and the provinces - and this phenomenon and the arrogance of the capital are obviously not particular to China. When asked about the exact nature of the obstruction of their work, Popular poets responded in various ways. Yi Sha, for instance, didn't see himself as a victim of obstruction at all. On the other hand, Popular poets were unanimous in their observation that in Beijing there are more "opportunities" than elsewhere: conferences, foreign media and scholar-translators, and the overall climate of a cultural center. This status undisputedly belongs to Beijing, not just in automated broadcasts on trains and planes approaching the capital but also according to angry Popular poets - even if they ridicule it, as does Yu Jian. A final point regarding geographical-cultural dividing lines in the Polemic is that they can of course be taken as a continuation of earlier moments in Chinese literary history. One recent example in poetry is the late 1970s rivalry between Huang Xiang's Guizhou-based Enlightenment troupe and authors associated with the Beijing journal Today. Another is Chengdu poet Zhong Ming's assertion of Southern poetic strength vis-à-vis a perceived Northern-capital hegemony in his 1982 unofficial anthology Born-Again Forest (次生林), and later in other publications such as the unofficial journal Image Puzzle (象周). A third is a general Southern connotation of Third Generation poetry from the mid-1980s onward, as the first challenge to the primacy of Today within the avant-garde.

Author personalities are also divided along institutional lines that go back to the 1980s. These lines run between unofficial journals of the kind known as "soulmate journals" or "peer journals" (同仁刊 物、同人刊物), the formation of which is governed by ties of literary allegiance - meaning a broadly shared poetics - and sometimes by regional identity. As noted, the concept of Intellectual Writing, in a proud not a derogatory sense, captures the ambition of Tendency (1988-1991), with Chen Dongdong, Xi Chuan, Ouyang Jianghe, Lao $\mathrm{Mu}$ and Wang Jiaxin as founding editors or close associates. In the early 1990s Intellectual Writing was associated with several other unofficial journals, most of all with the Southern Poetry Review (南方诗 志, 1992-1993); contributors to the Review included Chen Dongdong, 
Wang Jiaxin and Xi Chuan, among other authors who counted as Intellectuals during the Polemic. In his controversial anthology, Cheng Guangwei places Tendency and the Review on a pedestal, to the chagrin of Popular polemicists. The historical affinity of the Popular lies with Colloquial Poetry's milestone Them, the indecorous Macho Men and the iconoclast Not-Not, which advertised its poetics as "anti-cultural" or "pre-cultural." The picture is complete once we realize that the Tendency founders were in part motivated by the wish to counterbalance the impact of colloquializing and vulgarizing trends, in a conscious effort to have their own poetics recognized as an important part of the poetry scene.

There is no reason to doubt the significance of textual considerations in the emergence of individual journals of varying literary persuasion, meaning aesthetic - as distinct from "strategic" - preferences for this or that poetic style. But the personality factor does come into play when individual oeuvres develop and diverge or converge while personal ties of allegiance and enmity remain, whether according to the authors involved or to their audience. On that note, over and above the examples cited in the previous paragraph and their immediate connection to the Polemic, it is possible to observe an affiliation with either of the overarching categories of the Elevated and the Earthlyas well as "Northern" and especially "Southern" identities - for many of the unofficial journals that have helped shape the face of contemporary Chinese poetry from the late 1970s until today. ${ }^{23}$

Geographical-cultural and institutional dividing lines frequently coincide. Interwoven with them and discernible throughout the Polemic are biographical connections and personal ties of allegiancefriendships and so on - which can overlap with literary kinship but need not. Let's consider an example of what these various filters can do to the critical perception of literature.

Yu Jian and Yi Sha had been widely associated with one another long before they both came to occupy central positions in the Popular camp. Xi Chuan and Haizi continue to be mentioned in the same breath by poets, critics, scholars and other readers to this day. And granted, while Yu Jian and Yi Sha are colloquialists and demystifiers, Xi Chuan's and Haizi's early poetries share an aversion to these trends and are both marked by religious overtones. In their poetry, however,

${ }^{23}$ On North-South rivalries and unofficial journals, see Van Crevel 2007. 
$\mathrm{Yu}$ and $\mathrm{Yi}$ are worlds apart and so are the mature $\mathrm{Xi}$ Chuan and Haizi - even if any supposition about Haizi's development beyond the time of his death must remain conjecture. Indeed, one could argue that Yi Sha's poetry is akin to Haizi's and that Yu Jian's poetry is akin to Xi Chuan's, as follows. Essentially, the poetic voices in Yi Sha's and Haizi's oeuvres speak of who they are, and those in Yu Jian's and Xi Chuan's work speak of what they see, a distinction which provides a perfectly valid point of departure for the analysis and interpretation of literature. But both Yu Jian and Yi Sha are from the provincesnever mind the distance from Kunming to Xi'an - and both tend toward irreverence if not stylized trouble-making, especially when they write about poetry. Hence, they are lumped together. The same thing happens to Xi Chuan and Haizi, because they went to the same university and they were friends, and their friendship is documented in Xi Chuan's memorial essays after Haizi's suicide. Here, the Chinese adage that the text is like the person (文如其人) operates as an axiom rather than a general proposition that is defensible in itself but requires empirical, textual evidence before it may be applied to individuals or be used to demonstrate their literary kinship. In situations that ultimately arise out of an interest in the text itself, one is tempted to counter that the person is not like the text, or perhaps not invariably "as good as" the text (人不如其文).

Geographical-cultural, institutional and biographical angles help to expose a skeleton inside the tempestuous dynamics of the Polemic, but an answer to the question of what was at stake remains incomplete without some reflection on the sociology of Chinese poethood. As noted in the opening pages of this book, scholars such as Lloyd Haft and Michelle Yeh have shown how early modern Chinese poets grappled with the loss of the highly placed, well-defined social identity that their predecessors had self-evidently enjoyed for centuries. Even if the moderns themselves added to their loss by acts of their own initiative that aimed to change the face of Chinese poetry, prior to that their status had already suffered blows dealt out by socio-political forces that were bigger than literature. As such, the poets' identity crisis could not be stemmed by a return to the old ways. At the same time, turning themselves into a different, twentieth-century species wasn't made any easier by the bumpy road that poets traveled from the final years of the Qing dynasty to the advent of the Reform era in 1978. Those eight 
decades saw social upheaval, war, political terror and, generally, a society in which poetry was rarely left to its own devices. In this respect the publication of Today in 1978 opened up an entirely new space, beyond the pale of the official literary establishment.

In the late 1970s and the early 1980s, government suppression of the experiment would have been realistically possible, under the fickle winds of the PRC literary climate and its institutions - but after the failure of the 1983-1984 campaign to Eliminate Spiritual Pollution, as China entered into years of rapid and profound socio-cultural change, the avant-garde began to grow and ramify to where it outshone the establishment and that one-time common enemy of various new trends became largely irrelevant. In the same period, which witnessed what I have called multiple reinventions of contemporary poethood, conflicts and repositionings within the avant-garde began to occur, and the rampant commercialization of society - a new common enemy as perceived by many - didn't make the poets close ranks. Subsequently, in an admittedly crude scheme of things, the divergence and rivalry of the Elevated and the Earthly culminated in the Polemic of 1998-2000. As such, it was a showdown over the right of residence in the space opened up by Today, with older poets and critics expressing anxiety over what they perceived as the careless endangerment of the avantgarde's hard-won territory, and other bystanders registering everything from amusement to indignation at the poets' antics. The initial description of this space as beyond the pale no longer fits the central position it acquired in the 1990s: central, that is, within the "margins" of society, to where the avant-garde had repaired after its exceptional prominence in the late 1970s and the 1980s.

The Popular-Intellectual Polemic, then, was about nothing less than the legacy of Chinese poethood, meaning the right to see oneself and one's comrades-in-arms as torchbearers in a long-standing tradition, and the symbolic capital this should entail now that Chinese poetry had regained artistic independence. To zealous polemicists such as Yu Jian and Wang Jiaxin, torchbearer status called for the exclusion, loudmouthed or taciturn, of other poetic persuasions than their own. In addition, quite a few of the parties involved seemed to envisage the entitlement of poethood in not just literary but also social terms, and to yearn for a position in society closer to center stage. This reaffirms that although many avant-garde poets will declare that poetry should be autonomous from mainstream social development, they have not 
internalized this view. Albeit in a loose and abstract sense, they still subscribe to a time-honored poetics of literature to convey the Way, whether in a traditional or a modern frame of reference. This applies to not just the text but also the author. Indeed, several of the similarities in Popular and Intellectual discourse spring from what may be called their shared poetal views, especially the sheer importance both sides ascribe to poethood.

There are of course continuities with other polemics in modern Chinese poetry and modern Chinese culture at large, and with the phenomenon of abusive criticism as analysed by Michel Hockx for the Republican era, with a premodern history leading back to thirdcentury statesman-poet-theorist Cao Pi's famous declaration that "Literary men disparage one another-it's always been that way" (文 人相轻. 自古而然). ${ }^{24}$ For one thing, the present chapter has shown that the Polemic was a grim carnival of what Bourdieu calls positiontakings in the literary field. Of the substantive motivations behind such position-takings, which Yeh identifies as recurrent in debates throughout the modern era, one that obviously holds continued relevance is that of cultural identity, embodied in oppositions of Chinese and foreign, indigenous and Westernized, nativist and cosmopolitan. ${ }^{25}$ Another perennial issue is poetry's and the poet's contested social position, meaning their visibility and the degree of their involvement in and impact on socio-political development; but it is hard to say how far this discussion has extended into society beyond the poetry scene itself since the controversy over Obscure Poetry and the campaign to Eliminate Spiritual Pollution in the late 1970s and the early 1980 s. For one thing, what was left of traditional associations of poetry with national essence (国粹) at the time has thoroughly broken down during the avant-garde's subsequent development. On a general note, social change in the PRC has been so rapid and profound that it is unthinkable that an event like the Polemic would simply be a reprise of an earlier edition of more than a few years ago. More than anything else, this is visible in the unbridled rhetoric that characterized the Polemic, a crucial point being that substantial parts of the discourse displayed unmistakable irony — which, as noted at several points in this study, is

${ }^{24}$ Hockx 2003: ch 6. The translation of Cao Pi's words follows Owen 1992: $58 f f$.

25 Yeh 2001: 5ff. 
a distinguishing characteristic of contemporary Chinese poetry when compared to the recent past.

Did things look different than before, once the dust had settled? Incidentally, several Popular voices claim that the dust hasn't settled to this day. They are intent on continuing the struggle, so to speak. However, the Polemic "proper" lost its real momentum early in 2000, and when the many unresolved disputes flare up again — as they have done and will continue to do-it is unlikely that they will substantially change the issues or the stakes. They have in the meantime become the subject of scholarly analysis.

One thing the Polemic did change was the atmosphere on the poetry scene, whether viewed from a moral or a pragmatic perspective. Pre-Polemic days were of course not some sort of hunky-dory family gathering, but what basic solidarity and mutual respect existed throughout the avant-garde was seriously damaged. A development that has been more tangible and more important - again, this is according to Popular voices - is that the shake-up of reputations and hierarchies has encouraged poets who would previously have suffered from the phenomenon of obstruction, and given them concrete opportunities for publication. One example is the Epoch series, another the frantic activity displayed by unofficial poetry journals of recent years - such as Poetry Text, Poetry and People and The Lower Body - and most of all on the web. Still, these things might also have happened without the Polemic, just as slumbering conflicts might also have burst out, or strategic ambition manifested itself, without Cheng Guangwei's anthology. Leaving what-if questions aside, it is safe to say that the Polemic spurred reflection on the life and times of the avant-garde since the Cultural Revolution. It enhanced the retrospective reflex that tends to occur at the close of decades and centuries, even if there is nothing decimal to time itself.

In modern China, even more so than elsewhere, literary retrospectives are prone to end by directing our gaze from the past to the future. This illustrates a view of literature as a coherent body of self-evident significance, moving through time with a sense of direction-rather than, say, the somewhat unpredictable accumulation of artistic im- 
pulses held together by expression in a common linguistic medium, even if this is never entirely divorced from social development. This consideration provides some useful background to a question often raised by poets and critics in recent years, in formal and informal settings: was the Polemic a meaningful thing (有意义吗)?

The answers given in domestic critical discourse cover the full range from definitely yes to definitely no, which was to be expected if we consider how thoroughly divided opinions were at the time. In between, perhaps benefiting from the distance in time, there are recent, nuanced assessments in literary-historical and critical survey works such as those by Luo Zhenya in 2005 and Wei Tianwu in 2006, with Luo maintaining a neutral position and Wei cautiously siding with the Intellectuals, mostly because of the flaws in the Popular argument. Their differences aside, both authors decry the Popular distortion of key concepts such as "Intellectual," but also observe that the debate led to much-needed, increased contemplation of the state of the art. As for English-language scholarship, while Yeh holds that by scandalizing the poetry scene as a whole, the Polemic did more damage than good, Li Dian calls it a valiant collective effort by Chinese poets and critics to reconfigure the meaning of poetry in an age of commercialism and globalization. ${ }^{26}$

Perhaps an alternative to calling the Polemic meaningful or meaningless is to view it as a natural phenomenon - like a tidal wave, or a thunderstorm. The impact of such things merits contemplation, as do the forces that unleash them.

${ }^{26}$ Yeh 2007a: 34, Li Dian 2007. 


\section{Appendix: A Chronologigal Bibliography}

This bibliography includes everything from focused, partisan contributions by the foremost polemicists to writings of broader scope and greater critical distance that contain important passages on the debate. Especially for the former category, it lays claim to a reasonable degree of completeness. It stops in January 2002, when the Polemic "proper" had been over for some time and was among the topics treated in a state-of-the-field survey of Chinese literature at the end of the twentieth century (\#120).

Most entries appear in the previous two sections of this chapter. There are a few scholarly essays toward the end of the list that don't feed directly into the above discussion but may be of interest for future research. Entries are listed chronologically by year-month-(day), and alphabetically by author names in transcription. Beyond the month of publication, recorded in most Chinese books and journals, one cannot ascertain the exact time of appearance of these items as precisely as for newspapers and weeklies. Moreover, time between the completion of manuscripts and their publication varies. If the following record is therefore less than perfect, it still provides a reliable representation of the metatextual and discursive events that constituted the PopularIntellectual Polemic.

1 1998-02 | Cheng Guangwei (ed) 程光炜编, 《岁月的遗照: 九十年代文学 书系, 诗歌卷》 [A Portrait of Years Gone By: Literature of the Nineties, Poetry Volume], 北京: 社会科学文献

2 1998-02 | Cheng Guangwei 程光炜, 〈不知所终的旅行〉 Journey with Unknown Destination], introduction to entry 1: 1-21 (earlier published in 《山花》1997-11: 69-75)

3 1998-02 | Hong Zicheng \& Li Qingxi (eds) 洪子诚、李庆西主编, 《九十 年代文学书系》 [Literature of the Nineties], 北京: 社会科学文献

4 1998-02 | Hong Zicheng 洪子诚, 〈总序〉 [Foreword to the Series], in entry 1: 1-9

5 1998-03 | Yu Jian 于坚，〈诗歌之舌的硬与软: 关于当代诗歌的两类语言 向度〉 [The Hard and Soft of the Tongue of Poetry: On Two Different Directions in the Language of Contemporary Poetry], in 《诗探索》1998-1: 1-18 (reprinted in entry 12: 451-468)

6 1998-05 | Geng Zhanchun 耿占春, 〈一场诗学与社会学的内心论争〉 [An Inner Polemic of Poeticology \{i.e. Poetics\} and Sociology], in 《山 花》1998-5: 77-81 (reprinted in entry 85: 268-277)

7 1998-09 | Hou Ma 侯马, 〈抒情导致一首诗的失败〉 [Lyricism Leads to a Poem's Failure], in 《诗探索》1998-3: 150-154

8 1998-10-10 | Shen Haobo [Choushui] 沈浩波，〈谁在拿 “九十年代” 开 涮〉 [Who's Fooling “the Nineties”], first published under pseudonym 仇 
水 in 北京师范大学中文系五四文学社主办, 《五四文学报》, 10 October 1998: 1-2 (reprinted in December 1998 issue of 《东方文化周刊》[cited by the author and Yi Sha, without page numbers], 《文友》1999-1: 20-21 and entry 102: 540-544)

9 1999-02 | Shao Jian 邵建, 〈你到底要求诗干什么?〉 [So What Is It You Want from Poetry?], in entry 12: 403-419

10 1999-02 | Shen Qi 沈奇, 〈秋后算账 - 1998: 中国诗坛备忘录〉 [Square Accounts after the Autumn Harvest-1998: Memorandum on the Chinese Poetry Scene], in 《出版广角》1999-2: 22-26 (reprinted in entry 12: 384-395 and 《诗探索》1999-1: 18-30)

11 1999-02 | Xu Jiang 徐江〈玩弄中国诗歌〉 [Playing Chinese Poetry], in《文友》1999-2: 20-21

12 1999-02 | Yang Ke (ed) 杨克编, 《1998 中国新诗年鉴》[1998 Yearbook of China's New Poetry], 广州: 花城

13 1999-02 | Yang Ke 杨克, 〈《中国新诗年鉴》98工作手记〉 ['98 Work Notes on the Yearbook of China's Nerw Poetry], in entry 12: 517-520

14 1999-02 | Yu Jian 于坚, 〈穿越汉语的诗歌之光〉 [The Light of Poetry, Cutting through the Chinese Language], in entry 12: 1-17

15 1999-03 | Xie Youshun 谢有顺, 〈诗歌与什么相关〉 [What Does Poetry Relate to?], in 《诗探索》1999-1: 1-7 (earlier published in entry 12: 396-402)

16 1999-03 | Xu Jiang 徐江, 〈乌烟瘴气诗坛子〉 [The Noxious Poetry Scene], in 《文友》1999-3: 4-8

17 1999-04 | Tang Xiaodu (ed) 唐晓渡编, 《1998年现代汉诗年鉴》[1998 Yearbook of Modern Han Poetry], 中国文联: 379-380

18 1999-04 | Tang Xiaodu 唐晓渡, 〈后记〉 [Postscript], in entry 17: 1-2

19 1999-04 | Tang Xiaodu et al: Yearbook of Modern Han Poetry Editorial Committee 《现代汉诗年鉴》编委会, 〈序〉 [Preface], in entry 17

20 1999-04-02 | Xie Youshun 谢有顺, 〈内在的诗歌真相〉 The Inner True Face of Poetry], in 《南方周末》, 2 April 1999 (reprinted in entry 102: 526-530)

21 1999-05-14 | Tian Yong 田涌，〈十几年没 “打仗”: 诗人憋不住了〉 [No "Wars" for Over Ten Years: The Poets Can't Hold Themselves Back Any Longer], in 《中国青年报》, 14 May 1999: B4 (reprinted, citing the author's name as Tian Song 田诵, as 〈关于新诗发展方向又起论争〉 [A Polemic, Yet Again, on New Poetry's Course of Development], in 《新华文 摘》1999-8: 128)

22 1999-06 | Sun Wenbo 孙文波，〈我理解的90年代: 个人写作、叙事及其 他〉 [The Nineties as I See Them: Individual Writing, Narrativity and Other Things], in 《诗探索》1999-2: 26-37, 77 (reprinted in entry 85: 10-21)

23 1999-06 | Wang Jiaxin 王家新, 〈知识分子写作, 或曰 “献给无限的少数 人”〉 [Intellectual Writing, or "In Dedication to a Limitless Minority"], in《诗探索》1999-2: 38-52, 85 (reprinted in 《大家》1999-4: 83-89 and as the introduction to entry 85: 151-165)

24 1999-06 | Xi Du 西渡, 〈对几个问题的思考〉 [Thoughts on Various Issues], in《诗探索》1999-2: 53-67 (reprinted as 〈对于坚几个诗学命题 的质疑〉 [Challenging Some of Yu Jian's Poetical Propositions], in 《山 花》1999-7: 79-85 and as 〈写作的权利〉 [The Right to Write] in entry 85: 22-34) 
1999-06 | Xu Jiang 徐江, 〈俗人的诗歌权利〉 [Ordinary People's Right to Poetry], in 《诗探索》1999-2: 21-25

26 1999-06 | Zhang Qinghua 张清华, 〈一次真正的诗歌对话与交锋: “世纪 之交: 中国诗歌创作态势与理论建设研讨会” 述要〉 [True Dialogue and the Crossing of Swords in Poetry: A Report on "Turn of the Century: A Seminar on the State of the Art and Theory-Building in Chinese Poetry"], in《诗探索》1999-2: 68-77 (reprinted in《北京文学》1999-7: 59-62)

27 1999-06-15 | Cheng Guangwei 程光炜, 〈令谁痛心的表演〉 [A Performance to Make Whom Suffer?], in 《中国图书商报》书评周刊, 15 June 1999: 4

28 1999-06-15 | Xi Du 西渡, 〈民间立场的真相〉 [The True Face of the Popular Standpoint], in 《中国图书商报》书评周刊, 15 June 1999: 4

29 1999-06-15 | Yi Sha 伊沙, 〈两本年鉴的背后〉 [What's Behind These Two Yearbooks], in 《中国图书商报》书评周刊, 15 June 1999: 4

30 1999-07 | Chen Chao 陈超, 〈问与答: 对几个常识问题的看法〉 [Q \& A: Views on Some Issues of Common Knowledge], interview with Li Zhiqing 李志清, in《北京文学》1999-7: 63-64 (reprinted as 〈关于当下诗歌论争 的答问〉 [Q \& A on the Current Poetry Polemic] in entry 85: 63-70)

31 1999-07 | Han Dong 韩东, 〈附庸风雅的时代〉 [A Time That Supposedly Loves Culture], in 《北京文学》1999-7: 73-74 (reprinted in entry 102: 555-557)

32 1999-07 | Tang Xiaodu 唐晓渡, 〈致谢有顺君的公开信〉 [An Open Letter to Mr Xie Youshun], in《北京文学》1999-7: 65-68 (reprinted in entry 85: 75-81 and entry 102: 530-537)

33 1999-07 | Xi Chuan 西川, 〈思考比谩骂要重要〉[Contemplation Is More Important Than Abuse], in 《北京文学》1999-7: 75-76 (reprinted in entry 85 and entry 102: 537-540)

34 1999-07 | Xiangzi 湘子, 〈诗歌真的失去了读者吗〉 [Has Poetry Really Lost Its Readers?], in 《文友》1999-7: 8-9 (pseudonym of Yu Jian?)

35 1999-07 | Xie Youshun 谢有顺, 〈谁在伤害真正的诗歌?〉 [Who Is Doing Harm to True Poetry?], in 《北京文学》 1999-7: 69-73

36 1999-07 | Yu Jian 于坚, 〈抱着一块石头沉到底〉 [Clutch a Stone and Sink to the Bottom], interview with Tao Naikan 陶乃㑆, in《湖南文 学》1999-7: 70-80

37 1999-07-01 | Chen Jun 陈均, 〈诗歌不与什么相关〉 [What Poetry Does Not Relate to], in 《文论报》, 1 July 1999: 2

38 1999-07-01 | Shen Qi 沈奇, 〈谁伤害了90年代的诗歌〉 [Who Is It Has Harmed Poetry of the Nineties], in 《文论报》, 1 July 1999: 2

39 1999-07-01 | Xi Du 西渡, 〈诗歌是常识吗?〉 [Is Poetry Common Knowledge?], in 《文论报》, 1 July 1999: 2

40 1999-07-01 | Zang Di 藏棣, 〈诗歌: 作为一种特殊的知识〉 [Poetry as a Special Kind of Knowledge / Intellect], in 《文论报》, 1 July 1999: 2 (reprinted in 《北京文学》1999-8: 91-92 and entry 85: 42-45 and entry 102: 551-554)

41 1999-07-06 | Tang Xiaodu 唐晓渡, 〈读者来信〉 [Letter to the Editor], in 《中国图书商报》书评周刊, 6 July 1999 (reprinted as 〈请尊重批评的 底线〉 [Please Respect the Base Line of Criticism], in 周伦佑编, 《非 非·2000年特刊: 21 世纪汉语文学写作空间》: 206-208)

42 1999-07-12 | Jing Yi 静矣，〈99诗坛: “民间写作” 派与 “知识分子写作” 派之争〉 [The '99 Poetry Scene: The Battle of the School of "Popular Writing" and the School of "Intellectual Writing"], in 《北京日报》, 12 July 1999 
43 1999-07-26 | Jing Wen 京文，〈世纪之交的诗歌论争: 中国诗歌创作态势 与理论研讨会纪要〉 [Turn-of-the-Century Poetry Polemic: Summary of the Seminar on the State of the Art and Theory in Chinese Poetry], in《太原日报》, 26 July 1999: 5

44 1999-07-26 | Tang Jin 唐晋,〈“盘峰会议”的危险倾向〉 [Dangerous Trends at the "Panfeng Conference"], in 《太原日报》, 26 July 1999: 5

45 1999-07-26 | Wang Wei 王巍, 〈关注者的声音〉 [Voices of Concerned Onlookers], in 《太原日报》, 26 July 1999: 5

46 1999-07-26 | Wang Wei 王巍, 〈背景与其它〉 [Some Background and Other Things], in 《太原日报》, 26 July 1999: 5

47 1999-07-31 | Chen Jun 陈均, 〈于坚愚谁〉 [Who Does Yu Jian Think He Is Fooling], in 《科学时报》, 31 July 1999

48 1999-07-31 | Jiang Hao 蒋浩，〈民间诗歌的神话〉 [The Myth of Popular Poetry], in 《科学时报》, 31 July 1999 (reprinted in entry 102: 563-565)

49 1999-07-31 | Sun Wenbo 孙文波, 〈事实必须澄清〉 [The Facts Need Clarification], in 《科学时报》, 31 July 1999 (reprinted in entry 102: 547-548)

50 1999-07-31 | Tang Xiaodu 唐晓渡, 〈我看到.... [ [I See....], in《科学时 报》, 31 July 1999 (reprinted in entry 102: 570-572)

51 1999-07-31 | Wang Jiaxin 王家新, 〈也谈 “真相”〉 [More on the “True Face"], in 《科学时报》, 31 July 1999 (reprinted in entry 102: 544-547)

52 1999-08 | Hou Ma 侯马, 〈90年代: 业余诗人专业写作的开始〉 [The Nineties: The Beginning of Professional Writing by Amateur Poets], in 《北 京文学》1999-8: 95-96 (reprinted in entry 102: 567-568)

53 1999-08 | Shen Qi 沈奇, 〈何谓 “知识分子写作”〉 [What Is “Intellectual Writing”], in 《北京文学》1999-8: 94-95 (reprinted in entry 102: 565567)

54 1999-08 | Sun Wenbo 孙文波，〈关于 “西方的语言资源”〉 [On “Western Language Resources”], in《北京文学》1999-8: 93

55 1999-08 | Wang Jiaxin 王家新，〈关于 “知识分子写作”〉 [On “Intellectual Writing”], in 《北京文学》1999-8: 94

56 1999-08 | Xi Du 西渡, 〈为写作的权力声辩〉 [A Plea for the Right to Write], in 《北京文学》1999-8: 92-93

57 1999-08 | Yu Jian 于坚, 〈诗人及其命运〉 [The Poet and His Fate], in 《大家》1999-4: 80-83

58 1999-08-28 | Shen Haobo 沈浩波, 〈让论争沉下来〉 [Let the Polemic Sink In], in 《科学时报》, 28 August 1999 (reprinted in entry 102: 604-606)

59 1999-08-28 | Xu Jiang 徐江，〈敢对诗坛说 “不”〉 [Dare Say “No" to the Poetry Scene], in 《科学时报》, 28 August 1999 (reprinted in entry 102: 569-570)

60 1999-08-28 | Yi Sha 伊沙, 〈究竟谁疯了?〉 [So Who Is It Has Gone Mad?], in 《科学时报》, 28 August 1999 (reprinted in entry 102: 548550)

61 1999-08-28 | Yu Jian 于坚, 〈谁在制造话语权力?〉 [Who Is Producing Discursive Power?], in 《科学时报》, 28 August 1999

62 1999-09 | Jiang Tao 姜涛, 〈可疑的反思及反思话语的可能性〉 [Dubious Reflection and Possibilities of the Discourse of Reflection], in 《诗探 索》1999-3: 56-71 (reprinted in entry 85: 137-150)

63 1999-09 | Yu Jian 于坚, 〈真相: 关于 “知识分子写作” 和新潮诗歌批评〉 [Their True Face: On "Intellectual Writing" and New Tide Poetry Criti- 
cism], in 《诗探索》1999-3: 30-48 and 《诗参考》1999: 57-67 and entry 102: 587-604 (earlier published in 《北京文学》1999-8: 88-90, 81 [abridged])

64 1999-09 | Zhang Shuguang 张曙光, 〈90年代诗歌及我的诗学立场〉

[Poetry of the Nineties and My Poetical Standpoint], in 《诗探索》1999-3: 49-55 (reprinted in 《诗参考》 1999: 82-85 and entry 85: 3-9 and entry 102: 557-563)

65 1999-09 | Zou Jianjun 邹建军, 〈中国 “第三代” 诗歌纵横论: 从杨克主 编《1998中国新诗年鉴》谈起〉[Sweeping Remarks on China's “Third Generation" Poetry: On the 1998 Tearbook of China's New Poetry, edited by Yang Ke], in 《诗探索》1999-3: 79-87

66 1999-10| Cheng Guangwei 程光炜, 〈新诗在历史脉络之中: 对一场论争 的回答〉 [New Poetry Runs through History's Veins: In Response to a Polemic], in 《大家》1999-5: 190-193 (reprinted in entry 85: 120-125 and entry 102: 579-584)

67 1999-10 | Wang Jiaxin [Zi An] 王家新, 〈90年代诗歌纪事〉 [Annals of Poetry of the Nineties], in 《山花》 1999-10: 82-93 (reprinted in entry 85: 365-394, using pseudonym子岸)

68 1999-10 | Xie Youshun 谢有顺, 〈诗歌在疼痛〉 [Poetry Is Hurting], in 《大家》1999-5: 186-190 (reprinted in entry 102: 572-578)

69 1999-10-25 | Ding Mang 丁芒，〈所谓 “民间立场” 的实质：评广东版 《1998中国新诗年鉴》的理论话语〉 [The True Nature of the So-Called "Popular Standpoint": A Review of the Theoretical Discourse of the 1998 Yearbook of China's New Poetry, Guangdong Publishers], in《华夏时报》总 128期, 25 October 1999

70 1999-11 | Song Xiaoxian 宋晓贤, 〈中国诗坛的可悲现状〉 [The Sorry State of the Chinese Poetry Scene], in 《诗参考》1999: 98-99

71 1999-11 | Xu Jiang 徐江, 〈一个人的论争〉 [One Man's Polemic], in《诗 参考》1999: 96-97

72 1999-11 | Xu Jiang 徐江, 〈这就是我的立场〉 [This Is My Standpoint], in 《诗参考》1999: 86-90

73 1999-11 | Yang Xiaobin 杨小滨, 〈一边秋后算账, 一边暗送秋波〉 [Square Accounts after the Autumn Harvest While Stealthily Sending Autumn Waves], in 《诗参考》1999: 93-95 (reprinted in entry 85: 71-74)

74 1999-11 | Yi Sha 伊沙, 〈上一课〉 [Teach You a Lesson], in《诗参 考》1999: 100-101

75 1999-11 | Yi Sha 伊沙，〈世纪末: 诗人为何要打仗〉 [End of the Century: Why the Poets Are Going to War], in《文友》1999-11: 7-11 (reprinted as〈两个问题和一个背景: 我所经历的盘峰诗会〉 [Two Questions against One Background: The Panfeng Poetry Conference as I Experienced It], in 《诗参考》1999: 75-81 and with its original title in entry 102: 515-526)

76 1999-12 | Geng Zhanchun 耿占春, 〈没有终结的现实〉 [Unending Reality], in 《青年文学》1999-12 (cited by the author, without page numbers; reprinted in entry 85: 126-130)

77 1999-12 | Han Dong 韩东，〈论民间〉 [On the Popular], in entry 78: 1-18 (reprinted in entry 102: 464-478)

78 1999-12 | He Xiaozhu (ed) 何小竹编, 《1999中国诗年选》[Selected Chinese Poems of 1999], 西安: 陕西师范大学

79 1999-12 | He Xiaozhu 何小竹, 〈每年端出一些好吃的东西: 编辑工作手 记〉 [Serve Some Goodies Each Year: Editor's Note], in entry 78: 481483 
80 1999-12 | Sun Jilin 孙基林, 〈世纪末诗学论争在继续: 99中国龙脉诗会 综述〉 [The End-of-the-Century Polemic in Poetics Goes On: A Summary of the '99 Poetry Meeting in Longmai, China], in 《诗探索》1999-4: 51-61

81 1999-12 | Sun Wenbo 孙文波, 〈论争中的思考〉 [Thoughts from amid the Polemic], in 《诗探索》1999-4: 18-30

82 1999-12 | Yang Ke 杨克, 〈并非回应〉 [Not a Response], in《诗参 考》1999: 91-92 (reprinted in 《诗探索》1999-4: 31-33)

83 1999-12 | Zang Di 藏棣, 〈当代诗歌中的知识分子写作〉 [Intellectual Writing in Contemporary Poetry], in 《诗探索》1999-4: 1-5 (reprinted in entry 85: 42-45)

84 2000-01 | Chen Chao 陈超, 〈置身其中: 世纪末诗坛论争〉 [Position Oneself in the Midst of It: A Polemic on the Poetry Scene at the End of the Century], interview with Cao Jian 曹剑, in 《现代都市》2000-1: 35-38 (reprinted as 〈置身其中: 关于当下诗歌论争的答问〉 in 周伦佑编, 《非 非・2000年特刊: 21世纪汉语文学写作空间》: 229-242)

85 2000-01 | Wang Jiaxin \& Sun Wenbo (eds) 王家新、孙文波编, 《中国诗 歌: 九十年代备忘录》[Chinese Poetry: Memorandum for the Nineties], 北京: 人民文学

86 2000-01 | Wang Jiaxin 王家新, 〈从一种蒙蒙细雨开始〉 [Start from a Misty Drizzle], introduction to entry 85: 1-11 (earlier published in 《诗探 索》1999-4: 6-17 and 《诗参考》1999: 68-74)

87 2000-01 | Yi Sha 伊沙, 〈王家新伪史记〉 [Wang Jiaxin's Forged Records of the Historian], in 《文友》2000-1: 27-28 as part of〈激情点射〉 [Passionate Fixed Fire]

88 2000-01 | Zhou Zan 周瓒, “知识实践” 中的诗歌 “写作”〉 [The "Writing" of Poetry in "Knowledge / Intellectual Practice"], in entry 85: $46-62$

89 2000-01-15 | Miao Yushi 苗雨时,〈90年代诗坛的一场论争〉 [A Polemic on the Poetry Scene in the 1990s], in 《文论报》, 15 January 2000: 2

90 2000-03 | Geng Zhanchun 耿占春, 〈真理的诱惑〉 [The Temptation of Truth], in 《南方文坛》2000-5: 28-29

91 2000-03-08 | Xu Jiang \& Yi Sha 徐江、伊沙，〈将骂人进行到底〉 [Carry Abuse Through to the End], interview with Shen Lang 沈浪, in《社科新 书目》阅读导刊, 8 March 2000: 5

92 2000-03-28 | Bianzhe an 编者按 [Editor's Note] to 《社科新书目》阅读 导刊, 28 March 2000: 13

93 2000-03-28 | Gu Changjun 谷昌君, 《“知识分子写作” 或曰 “新左派”: 《中国诗歌九十年代备忘录》导读〉 ["Intellectual Writing," or “The New Left": A Reader's Guide to Chinese Poetry: Memorandum for the Nineties], in 《社科新书目》阅读导刊, 28 March 2000: 13 (reprinted in 《诗参 考》2000: 73-74)

94 2000-03-28 | Shen Haobo 沈浩波, 〈真正的民间精神的光〉 [The Light of the True Popular Spirit], in 《社科新书目》阅读导刊, 28 March 2000: 13 (reprinted in 《诗参考》2000: 72-73)

95 2000-03-28 | Zhongdao 中岛，〈一场蓄意制造的阴谋〉 [A Premeditated Conspiracy], in 《社科新书目》阅读导刊, 28 March 2000: 13 (reprinted in 《诗参考》2000: 71-72)

96 2000-04 | Xie Youshun 谢有顺，〈诗歌在前进〉 [Poetry Is Advancing], in 《山花》2000-4: 76-81 (reprinted as 〈序〉 [Preface], in entry 102: $1-16)$ 
97 2000-05-28 | Sun Wenbo 孙文波, 〈“知识分子写作”发言〉 [Statement on Behalf of “Intellectual Writing"], in 《社科新书目》阅读导刊, 28 May 2000: 15

98 2000-05-28 | Yi Sha 伊沙, 〈“民间立场” 发言〉 [Statement on Behalf of the "Popular Standpoint"], in《社科新书目》阅读导刊, 28 May 2000: 16

99 2000-05-28 | Yu Jian 于坚,〈“民间立场”发言〉 [Statement on Behalf of the “Popular Standpoint"], in《社科新书目》阅读导刊, 28 May 2000: 16

100 2000-05-28 | Zang Di 藏棣, “知识分子写作” 发言〉 [Statement on Behalf of “Intellectual Writing”], in 《社科新书目》阅读导刊, 28 May 2000: 15

101 2000-06 | Shen Qi 沈奇,〈中国诗歌: 世纪末论争与反思〉 [Chinese Poetry: A Polemic and Reflection at the End of the Century], in 《诗探 索》2000-1/2: 17-34 (reprinted in 周伦佑编, 《非非・2000年特刊: 21世纪 汉语文学写作空间》: 209-228, entry 102: 577-591 and《诗参考》2000: 55-65)

102 2000-06 | Yang Ke (ed) 杨克编, 《1999中国新诗年鉴》[1999 Yearbook of China's New Poetry], 广州: 广州

103 2000-06 | Yang Ke 杨克, 〈《中国新诗年鉴》99工作手记〉 ['99 Work Notes on the Yearbook of China's New Poetry], in entry 102: 652-656

104 2000-06 | Zeng Feiye 曾非也，〈看诗坛热闹〉[Check Out the Action on the Poetry Scene], in entry 102: 584-586

105 2000-06-28 | Fang Chen 方辰，〈《1999中国新诗年鉴》出来啦! 〉 Out Now! The 1999 Yearbook of China's New Poetry], in《社科新书目》阅读导 刊, 28 June 2000: 15

106 2000-07 | Ma Junhua 马俊华, 〈诗坛夺嫡〉 [Infighting on the Poetry Scene], in 《诗参考》2000: 79-80

107 2000-07 | Tang Xin 唐欣，〈写作何必 “知识分子”〉 [Why Should Writing Be "Intellectual"], in 《诗参考》2000: 68-69

108 2000-07 | Xu Jiang 徐江, 〈眼睛绿了〉 [Eyes Turned Green], in《诗参 考》2000: 75-78

109 2000-07 | Yan Li 严力, 〈说教和包装〉 [Preaching and Packaging], in 《诗参考》2000: 66-67

110 2000-07 | Zhongdao 中岛，〈我对《1999中国新诗年鉴》的几点看法〉 [My Ideas about the 1999 Yearbook of China's New Poetry], in 《诗参考》2000: 69-70

111 2000-08 | Tang Xiaodu 唐晓渡,〈诗坛 “后厚黑学”, 或开塞露主义〉 ["Post-Thick-n-Blackology," or Laxativism on the Poetry Scene], in周伦佑 编，《非非・2000年特刊: 21 世纪汉语文学写作空间》: 197-205

112 2000-10 | Zhou Zan 周瓒，〈当代文化英雄的出演与降落: 中国诗歌与诗 坛论争研究〉 [The Rise and Fall of Contemporary Cultural Heroes: A Study of a Polemic in Chinese Poetry and the Poetry Scene], in 戴锦华 编, 《书写文化英雄: 世纪之交的文化研究》, 南京: 江苏人民: 72-129

113 2000-11 | Li Zhen 李震, 〈先锋诗歌的前因后果与我的立场〉 [The Ramifications of Avant-Garde Poetry and My Standpoint], in 《唐》1: 144-149 (reprinted in entry 116: 596-604)

114 2000-12 | Shen Haobo \& Hou Ma \& Li Hongqi 沈浩波、侯马、李红旗, 〈关于当代中国新诗一些具体话题的对话〉 [Dialogue on Some Concrete Issues in Contemporary Chinese New Poetry], in《诗探索》2000-3/4: 51-59 
115 2000-12-11 | Wang Gan 王干, 〈走出90年代〉[Out of the Nineties], in 《太原日报》, 11 December 2000

116 2001-07 | Yang Ke (ed) 杨克编,《2000中国新诗年坚》[2000 Yearbook of China's New Poetry], 广州: 广州

117 2001-10 | Lan Dizhi 蓝棣之, 〈论当前诗歌写作的几种可能性〉[On Various Possibilities for Writing Poetry in This Day and Age], in 《文学评 论》2001-5: 80-87

118 2001-12 | Huang Tianyong 黄天勇, 〈反叛与游戏: 对中国20世纪最后 15 年诗歌实验的考察〉 [Rebel and Play: An Examination of Chinese Poetic Experiment in the Final 15 Years of the Twentieth Century], in 《诗探 索》2001-3/4: 64-74

119 2001-12 | Xi Yunshu 席云舒，〈困顿中的反思: 关于世纪之交的诗坛现 状及其局限〉 [Reflections in the Midst of Fatigue: On the State of the Poetry Scene at the Turn of the Century, and Its Limitations], in 《诗探 索》2001-3/4: 55-63

120 2002-01 | Cao Wenxuan 曹文轩, 〈第十章・诗人诗话〉 [Chapter Ten: Poets on Poetry], in 《20世纪末中国文学现象研究》 [A Study of Phenomena in Chinese Literature at the End of the Twentieth Century], 北京: 北京大学: 277-308 